\title{
THE BOARD OF THE NEW CODE OF THE INDIES (1776-1820): OBSERVATIONS AND CLARIFICATIONS FOR A REVISED INTERPRETATION
}

\author{
Dr. José María Vallejo García-Hevia
}

Professor of History of Law at the University of Castilla-La Mancha

Correspondence:

josemaria.vallejo@uclm

\section{How to cite this paper}

Vallejo García-Hevia, José Maria (2019): The board of the New Code of the Indies (1776-1820):

observations and clarifications for a revised interpretation. Spanish Journal of Legislative Studies.

(1), p1- 57. DOI: https://doi.org/10.21134/sjls.v0i1.1710 


\section{Resumen}

El estudio del proceso de formación y el análisis del contenido del conocido como Nuevo Código de Leyes de las Indias, aprobado, sancionado y promulgado por Carlos IV, en 1792, pero no publicado de forma general y conjunta, permite llegar a nuevas conclusiones y a una renovada interpretación historiográfica sobre su origen, su elaboración y las causas de su secreta vigencia, excepción hecha de doce de sus leyes, mandadas aplicar, por parte de las autoridades gubernativas y judiciales indianas, entre 1789 y 1804 . Años antes, en 1776, Carlos III había ordenado que la ya centenaria Recopilación de Indias, de 1680, fuese adicionada e ilustrada con las disposiciones normativas promulgadas con posterioridad. Pero, de los nueve libros recopilados por mandato de Carlos II, a finales del siglo XVII, el único que terminaría siendo propuesto por la Junta del Nuevo Código, para ello creada, en las postrimerías del XVIII, y finalmente aceptado, fue el Libro I, que era una compilación de la legislación borbónica sobre el gobierno eclesiástico de América, que giraba alrededor de su institución clave, el Patronato Real. El manejo de las actas de dicha Junta que se conservan (1776-1785), junto con el proyecto de Libro I, propuesto por Juan Crisóstomo de Ansotegui (1780), entre otras fuentes documentales, posibilita despejar los múltiples interrogantes que se ciernen sobre dicha obra legislativa, cuales los de por qué se trata de una anacrónica y parcial Recopilación oficial y no de un completo Código ilustrado; a qué se debió la lentitud recopiladora de la Junta en sus disputa con el Consejo Real de las Indias; o cuáles fueron, finalmente, las verdaderas causas, más allá de las tradicionales regalistas, por las que no terminó sien- do publicado, cuando ya la Revolución Francesa, de 1789, había prendido por toda Europa y amenazaba la estabilidad de sus vetustas Monarquías absolutistas.

\section{Palabras clave}

Código, Recopilación, Ley, América, Real Consejo de las Indias, Gobierno eclesiástico 


\section{Abstract}

The study of the formation and the analysis of the content of the well-known New Code of Laws of the Indies, approved, sanctioned and promulgated by Carlos IV of Spain in 1792, but not wholly and generally published, permits new conclusions and a renewed historiographical interpretation about its origin, development and the reasons behind the secrecy of it being in force, with the exception of twelve of its laws, ordered to be applied by the by governmental and judicial authorities of the Indies between 1789 and 1804. Years earlier, in 1776, Carlos III, the King of Spain, had ordered the century-old Law code of the Indies (1680) to be added to and enlightened with the provisions which would be enacted at a later time. However, out of the nine books compiled by order of Carlos II in the late $17^{\text {th }}$ Century, only Book I ended up being proposed and finally accepted by the Board of the New Code created for this purpose in the late $18^{\text {th }}$ Century. This Book was a compilation of Bourbon legislation of the ecclesiastical government of America, which revolved around its key institution the 'Patronato Real". Consultation of the preserved minutes of this Board (1776-1785), together with the project of Book I, proposed by Juan Crisóstomo de Ansotegui (1780), among other documentary sources, enables many unanswered questions overshadowing this legislative work to be clarified: why it is an anachronic and partially official Compilation and not a complete enlightened code of laws; the reasons for the Board's slowness in its disputes with the Royal Council of the Indies; finally, the real causes, beyond traditional 'regalismo' 2 , for the New Law Code not to be published, when the French Revolution of 1789 reverberated throughout Europe and threatened the stability of its ancient absolutist Monarchies.

\section{Keywords}

Code, Compilation, Law, America, Royal Council of the Indies Ecclesiastical Government.

\footnotetext{
${ }^{1}$ The Patronato Real or Patronato Regio (literally Royal Patronage) was a system for controlling the appointments of church officials and the management of church through concordats with the Holy See.

${ }^{2}$ Regalismo, the set of theories and practices sustaining the personal right of the sovereigns over certain regalías, especially those which clashed with the rights of the Pope.
} 
SUMMARY*: 1. Preface. 2. The development of the New Code of 1792 and its vicissitudes: some observations and clarifications 3 . The contents of the New Code of the Indies: more observations and its necessary revision. 4. The New Law Code of the Indies: a renewed interpretation about its contents and preparation 5. Colophon.

“Y salió disparado, zanjando así el debate que, como cualquier disputa sobre literatura, filosofía u otra materia, habría podido durar siglos, pues cada una de las partes no hacía sino repetir su propio argumento". (A. Manzoni, Los Novios) ${ }^{3}$

\section{PREFACE}

The Indies, the New World from the $16^{\text {th }}$ to $18^{\text {th }}$ century, and even in the 19th century, was wholly ecclesiastical and theocratic. In fact, European America had prevailed over native America, conquered by the Spanish Catholic Monarchy and evangelised by the Apostolic Catholic Church. From a doctrinal point of view, the Spanish Crown always professed, defended and diffused the dogmas of the Church throughout its European and American Kingdoms. From a jurisdictional perspective, it also endorsed ecclesiastical regulations, raising them to the level of civil laws, especially the disciplinary decrees of the Council of Trent (1545-1563). However, it was also true that the Crown and its Royal Council of the Indies always broadly interpreted pontifical privileges and concessions of titles of conquest, territorial control and evangelisation of the New World, as well as other rights which would benefit their temporal interests.

Consenting to a petition from this Royal Council in 1776, Carlos III ordered the already century-old Indian Compilation (RI) of 1680 to be added to and enlightened with provisions which would be enacted at a later date. The Board of the Laws of the Indies or of the New Code was constituted and entrusted with this task. It took them until 1820 to carry out their work, which in the midst of the War of Independence was at times diffuse and confusing. The only tangible result appeared in 1792 with Book I of this New Code, which was approved, sanctioned and enacted by Carlos IV, but not published. Nevertheless, an exception was made with respect to a dozen laws included in nine royal charters, ordered to be fragmented and circulated successively and casuistically for their application by governmental and judicial authorities in the Indies between 1789 and 1804. Even in Book I alone, this New Code of the Indies (NCI) was intended to be a compilation of all the Bourbon legislation regarding the ecclesiastical government of America. From its Title II, the Patronato Real appeared as the institution that constituted the cornerstone of this legislation.

Indeed, the 1792 work was not a Law code as such, but an updated official Compilation-yet another from Castilian historical Law-, in this case of the Indies. The idea of the Code, conceived by the legal Enlightenment of the $18^{\text {th }}$ century, was built

*Una sucinta parte de esta monografía, en concreto su epígrafe 2, ha sido publicado, bajo el título de "El Nuevo Código de Indias de 1792: Sus vicisitudes de elaboración", in Actas y Estudios del XIX Congreso del Instituto Internacional de Historia del Derecho Indiano, coordinadas por Thomas Duve, 2 vols., Madrid, Dykinson, 2007, vol. I, pp. 475-494.

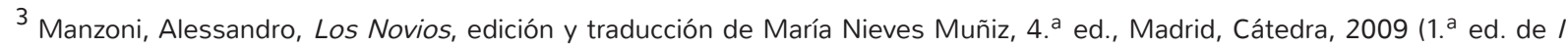
promessi sposi, Milán, Vincenzo Ferrario, 1827; $2^{a}{ }^{a}$ ed. definitiva y corregida lingüísticamente, en fascículos, Milán, Guglielmini y Redaelli, 1840-1842) cap. II, pp. 96-110; la cita, en p. 106.
} 
on the theoretical denial of the political and even social and economic order of that time, which was the Ancien Régime with its deep medieval roots. For the Indies, the 1792 code would have implied an essential and constitutive contradiction, since if the Code presupposed a legislative conception of legal order, which sooner or later would necessarily result in the presence of a constitutive legislative power, such a power could neither exist or be represented by the Kings of the absolute Monarchies. Nor could the coded laws survive, or even appear in the heart of a legal order that was formally determined by doctrine and history, and materially inherent in secular rights, exceptions and exemptions: corporative, feudal, jurisdictional (plurality and contradictions in jurisdictional authority) amortisation and entailment, etc. ${ }^{4}$.

The New Code of the Indies was therefore neither New nor a Code and not even enlightened. In contrast to those authors who conceive $18^{\text {th }}$ century Spanish Law as a modern regulatory expression, unique in the context of western legal rationalism, whose advanced legal absolutism anticipated the $19^{\text {th }}$ century coding process, it should be concluded that the so-called Indian
New Code was an anachronic compilation of laws, which in 1792 lacked innovation. While the French Revolution reverberated throughout Europe and the parliamentary Monarchy of Louis XVI, in existence since the 1791 constitution, was guillotined, in Spain the absolutist Monarchy continued to be considered the only admissible form of government and it became deeply entrenched in 'regalismo' and sovereign rule. In the minutes of the Board of the New Code, nothing was even debated about the historical Constitution or the Fundamental Laws of the Hispanic Monarchy nor the balance of powers in favour of the rights and freedoms of its subjects. Their only concern continued to be the old regalías ${ }^{5}$ of the Crown, rooted in the outdated theses of the Indian 'Real Patronato' and Vicariate ${ }^{6}$.

The surprising fact that the New Code was enacted in 1792, but not published, was not because the Church would oppose its presumably exacerbated 'regalismo', as has been supposed, but due to an evident political cause. In his cordon sanitaire policy against revolutionary France, Floridablanca, Minister of State for Carlos III and Carlos IV, did not want to cause any displeasure

4 Vid. Vallejo García-Hevia, J. M., La Segunda Carolina. El "Nuevo Código» de Leyes de las Indias. Sus Juntas recopiladoras, sus Secretarios y el Real Consejo (1776-1820), 3 tomos, Madrid, Agencia Estatal Boletín Oficial del Estado, 2016.

${ }^{5}$ Regalía is the inherent and exclusive rights of the King's sovereign power or royal privileges.

${ }^{6}$ Así, un ejemplo de defensa del reformismo normativo borbónico como una vía alternativa a la modernidad jurídica es el que proporciona Ezequiel Abásolo, "La Junta Revisora del Nuevo Código de las Leyes de Indias y las concepciones jurídicas dieciochescas», en Alejandro Guzmán Brito (ed.), El Derecho de las Indias Occidentales y su pervivencia en los Derechos Patrios de América. Actas del XVI Congreso del Instituto Internacional de Historia del Derecho Indiano, 2 vols., Valparaíso, Ediciones Universitarias, 2010, vol. I, pp. 51-62; luego reproducido en su "Animado Yo de los mismos deseos de mi Augusto Padre». Estudios y documentos sobre la fijación del Derecho de la Monarquía Española durante la época de Carlos IV, en Eduardo Martiré (coord.), La América de Carlos IV. Cuadernos de Investigaciones y Documentos, vol. IV, Buenos Aires, Instituto de Investigaciones de Historia del Derecho, 2009, pp. 15-32. Por el contrario, ahondando en la naturaleza paternalista, tradicional y absolutista del discurso jurídico-político ilustrado, Francisco Luis Pacheco Caballero, "Retórica, tópica y legislación en el siglo xviii», en Aquilino Iglesia Ferreirós (ed.), Estat, Dret i Societat al segle XVIII. Homenatge al Prof. Josep M. Gay i Escoda, Barcelona, Associació Catalana d'Història del Dret Jaume de Montjuïc, 1996, pp. 479- 503; Pedro Álvarez de Miranda, Palabras e ideas: el léxico de la Ilustración temprana en España (1680-1760), Madrid, Anejos del Boletín de la Real Academia Española, 1992, pp. 43-67; y Clara Álvarez Alonso, "La dudosa originalidad del regalismo borbónico», en A. Iglesia Ferreirós (ed.), Estat, Dret i Societat al segle xviii. Homenatge al Prof. Josep M. Gay i Escoda, pp. 169-206. 
in the Church, by an even more pronounced 'regalismo' in the Indies than in 1680. This was because the secular sustenance of the questioned absolutist monarchies was being supported from the Holy Seat by the ecclesiastical authorities: the clergy with their sermons and the friars preaching in their metropolitan dioceses and provinces, and through customs the Holy Office was pursuing the ideas, followers, books and revolutionary propaganda. Hence, the secret enforcement of a civil or temporal 'regalista' Compilation of ecclesiastical matters which was both traditional and essential for the delicate balance between the Throne and the Altar in a turbulent Europe of the Ancien Régime at the end of the century.

\section{THE DEVELOPMENT OF THE NEW CODE OF 1792 AND ITS VI- CISSITUDES: SOME OBSERVA- TIONS AND CLARIFICATIONS}

The formal and material birth of the New Code, since it was not legal as a public corpus legis, originated from two consultations by the Royal and Supreme Council of the Indies: one on $20^{\text {th }}$ March 1771, when it was brought to the attention of the then sovereign, Carlos III, that there was a need to add to and enlighten the laws of the 1680 Compilation with the resolutions and further provisions "convenientes a la constitución del gobierno actual de aquellos Reinos" of the New World; and another on $10^{\text {th }}$ May 1773 which noted that the laws of the Indies should not be annotated or commented. The belated resolution to the latter consultation was adopted in a Royal
Decree (RD) of $9^{\text {th }}$ May 1776, which ordered the creation of a New Code of Indian laws, although with the prohibition to ever allow annotations or comments about them, to be entrusted to two commissioned lawyers: Miguel José Serrador, second officer to the Secretariat of State and the Office of the Indies; and Juan Crisóstomo de Ansotegui, fiscal agent of the Council of Indies promoted to a supernumerary post for the Royal Audience of the 'Casa de Contratación' of Cadiz. Both royal commissioners would have to be supervised by a Royal Board, which was constituted at that time whose members were: Manuel Lanz de Casafonda, Felipe Santos Domínguez, José Pablo de Agüero, Jacobo de la Huerta and Antonio Porlier, and Manuel José de Ayala as secretary. All of them were magistrates and minister-councillors of the Indies, except for Porlier, prosecutor of the Council of the Indies of the New Spain, and Ayala, fourth officer of the previously mentioned Secretariat or Ministry of Indies ?

The first session of the Board of the New code was held on Sunday $16^{\text {th }}$ June 1776, and it was agreed to keep a book of the minutes of the meetings, signed by its members and authorized by the secretary. The commissioners, Serrador and Ansotegui, entrusted with the compilation, attended the second session on Friday $21^{\text {st }}$ June 1776 and were informed that as decreed by the King they should initiate the compilation work. They should start by comparing, verifying and gathering charters from the new post-compilations and especially repeals and amendments of the laws compiled in 1680 and published in 1681. They were authorised to issue writs to the Mi-

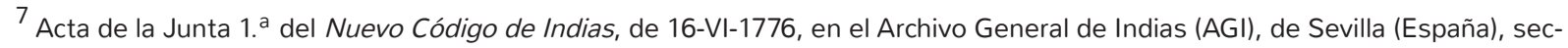
ción de Indiferente General, legajo 1.653, folios $1 \mathrm{r}-2 \mathrm{r}$. El Libro de los acuerdos de la Junta nombrada para corregir y adicionar las Leyes de Indias, cuyas sesiones se desarrollaron entre la primera de las celebradas, el domingo, 16-VI-1776, y la número 250, del miércoles, 18-V-1785, aunque consta la no asistencia y celebración de reuniones hasta el mismo lunes, 13-VI-1785, se custodia, en efecto, en AGI, Indiferente General, leg. 1.653, ff. 1 r-415 v.
} 
nistries of the Council of the Indies of the New Spain and Peru, so that they would provide the charters and other papers required. However, the third session would not take place until five years later on $25^{\text {th }}$ June 1781 . What was the reason for such a long wait? In accordance with the abovementioned $\mathrm{RD}$ of $9^{\text {th }}$ May 1776, the laws that Serrador and Ansotegui were to compile, consolidate and draw up for the New Code had to be revised by ministers-members of the Board, but also reviewed by the whole of the Council of the Indies afterwards, before being finally approved or not by the King. That is to say, the Board of the New Code created in 1776 was directly dependent on the Royal Council in this first phase of its institutional activity and lacked decisive legal and political autonomy. Hence, it was necessary to wait for the royal commissioners Serrador and Ansotegui to conclude their task, at least partiaIly, regarding the first of the books of the 1680 Compilation. This book was dedicated to the Holy Catholic Faith in general, and to the Church in the Indies, especially to: its prelates, bishops, archbishops; secular and regular clergy; jurisdictional immunity; the 'Patronato Real Indio'; provincial and synodal councils; tithes, hospitals and guilds, Universities and General studies, publication of books... With respect to the commissioners compiling the books, Serrador would contribute little or nothing, since he had to retire on $23^{\text {rd }}$ February 1778 , and in acknowledgement received a third of his wage as pension. Therefore, the compilation work would revert to Juan Crisóstomo de Anso- tegui alone, a qualified lawyer from Alava, native to Laguardia, and as already stated since 1754 a supernumerary fiscal agent of the Council of the Indies in relation to the Peru negotiation ${ }^{8}$.

This would explain, therefore, the notable delay in the meetings and minutes of the Board of the New Code. Ansotegui took four years, from June 1776 to July 1780, to draw up the laws of Book I, comprising 24 titles, the same ones as in book I of the 1680 Compilation, whose external structure he followed closely, and which was presented to the Monarch on $21^{\text {st }}$ July 1780 . This Book I, proposed by Ansotegui, was submitted to the Council of the Indies accompanied by a RD of $7^{\text {th }}$ September 1780 which regulated the Board's revision procedure, and which named it the New Compilation or Law Code of the Indies. The Board would set aside two days a week to meet during audience and tribunal hours in the Council Room allocated to them, where the ministers-members would proceed with the "revisión y examen de las leyes que el citado libro contiene, haciendo concurrir al comisionado Ansotegui cuando la Junta lo necesite y regulare conveniente, a fin de que los informe y manifieste las cédulas, resoluciones y demás documentos que haya tenido presente, sin perjuicio de la fe que debe darse a sus aserciones de hecho, en este punto". When the Board came across a serious difficulty in any of the new or reformed laws, it had to consult with the King directly, while continuing with the examination and correction of the following laws. Given the importance of their mission, the Board

\footnotetext{
${ }^{8}$ Actas de las Juntas 2. ${ }^{a}$ y $3 .^{\text {a }}$ del Nuevo Código, de 21-VI-1776 y 25-VI-1781 (AGI, Indiferente General, leg. 1.653, ff. 2 r y v, y 3 r-10 r). Y Muro Orejón, Antonio, "Estudio general del Nuevo Código de las Leyes de Indias», en el Homenaje al Doctor Don Antonio Muro Orejón, 2 vols., Sevilla, Universidad, 1979, vol. II, pp. 3-89, en concreto, pp. 18-19 y 38-39; Manzano, Juan, Las "Notas" a las Leyes de Indias, de Manuel José de Ayala, Madrid, 1935, pp. 53-56 y 143-156; Id., El Nuevo Código de las Leyes de Indias. (Proyecto de Juan Crisóstomo de Ansotegui), Madrid, 1936, pp. 3-9; e Id., "Estudio preliminar» a su edición de las Notas a la Recopilación de Indias. Origen e historia ilustrada de las Leyes de Indias, de Manuel José de Ayala, 2 tomos, estudio y transcripción de..., Madrid, 1945 y 1946, t. I, pp. Cl-CVI; y Gómez Gómez, Margarita, Actores del documento. Oficiales, archiveros y escribientes de la Secretaría de Estado y del Despacho Universal de Indias durante el siglo XVIII, Madrid, Centro de Estudios Políticos y Constitucionales (CEPyC), 2003, pp. 435-437.
} 
would continue with their revision although some of the members were absent from the meetings. In any case, the monarch would also name new members if the Board considered it necessary and requested it in writing or by representation. Both the RD of $7^{\text {th }}$ September 1780 and Book I by Ansotegui were sent to the public prosecutors of the Council of Indies: Antonio Porlier future I Marqués de Bajamar prosecutor for the New Spain, who was also a member of the Board; and José de Cistué y Coll prosecutor for Peru. According to their explanation and as consulted with the Council, the secretary of State and the Office of the Indies, José de Gálvez, informed, by the Royal Order (RO) of $30^{\text {th }}$ November 1780, that Carlos III had determined that the Board sessions would be held on Mondays and Wednesdays every week in the Second Chamber of the Government Council $^{9}$.

However, in the months between September 1780 and May 1781, Ansotegui died and the secretary, Ayala, resigned because he was unhappy at not being rewarded for his work of gathering charters and consultations, and as scribe of the laws compiled in 1680 (Cedulario, Miscelánea, Diccionario, Notas). As a result, Carlos III named Luis Peñaranda as substitute to serve the Secretariat of the Board notifying him of his appointment on $8^{\text {th }}$ June. At last, the third session could be held on $25^{\text {th }}$ June 1781, with the only absentee being Agüero due to illness. Besides the previous changes and royal resolutions, Casafonda, a senior member and also spokesman for the Council of Indies, where he was interim governor, became aware of another RO of $4^{\text {th }}$ June 1781. In this RO, Gálvez had asked him whether the Board was going to continue with the examination of Book I despite the disappearance of its compiler, since the King wished them to go on revising the laws until the work had been completed. In view of this, the Board agreed that through an authorized inventory Ayala, as outgoing secretary, should hand over all the books, papers and documents that he may have in his power to Peñaran$\mathrm{da}$, the incoming secretary, while the dean-president Casafonda should also hand over Book I by Ansoteguiano.

The fourth session held on $4^{\text {th }}$ July 1781 had even greater transcendence, when the Board observed a clear contradiction between two royal provisions, the cited RDs of $9^{\text {th }}$ May 1776 and that of $7^{\text {th }}$ September 1780. In fact, in 1776 the Board depended on the Council of the Indies, that is to say, its legal authority in the revision of the compilation was subordinate to the decisive evaluative authority of the Council, which was the administrative entity entrusted with consulting all legislative matters for their royal approval. In 1780, however, a radical modification was introduced when it was established that if the Board should come across a serious difficulty in any of the new uncompiled laws, that it wanted to include in the New Code, it (the Board, not the Council) could consult directly with the King about this. It was clear to the Board that as from 1780 it had a decisive legislative authority regarding all those laws that did not raise "perplejidad, duda o dificultad", and it was authorised to consult the monarch about those laws that caused serious doubts or difficulties without any council intermediary. Despite all the above, Casafonda, Domínguez, Huerta and Porlier agreed to send a consultation to Car-

${ }^{9}$ AGI, Contratación, leg. 5.786, lib. 3, ff. 34 r-36 v y 57 r-58 v. Acta de la Junta 3. ${ }^{a}$ del Nuevo Código de Indias, de 25-VI-1781 (AGI, Indiferente General, leg. 1.653, ff. 3 r-10 r); y Manzano, J., El Nuevo Código de las Leyes de Indias. (Proyecto de Juan Crisóstomo de Ansotegui), pp. 9-13; e Id., "Estudio preliminar" a las Notas a la Recopilación de Indias, de Manuel José de Ayala, t. I, pp. CVI-CX. 
Ios III, dated $6^{\text {th }}$ July 1781, asking him to explicitly clarify the Board's legislative competences, responsibilities and faculties. Legally, while the law of the Compilation of 1680, II, 2, 15 was in force -according to number 32 of the Royal Ordinances of the Council of the Indies of 1571, and 15 of the later Indian synodal Ordinances of 1636- the authority to create new laws or renew the old ones corresponded to the advisory ministers of the Plenary Council of the Indies, with a majority of two thirds and subsequent approval by the sovereign. The royal resolution to this consultation of $6^{\text {th }}$ July 1781 published in the $5^{\text {th }}$ session on $8^{\text {th }}$ August 1781 was completely favourable to the Board: the revision of the laws of the New Code became exempt from the application of the Royal Ordinances of the Council of the Indies and subsequently from the validity of $\mathrm{RI}, \mathrm{II}, 2,15$, and only the RD of $7^{\text {th }}$ September 1780 was applicable . $^{10}$

So, this was how five years after its constitution, in its $6^{\text {th }}$ session on $13^{\text {th }}$ August 1781 , the Board was able to commence with the examination of Book I by Ansotegui of 1780, starting with title I. De la Santa Fe Catholica, and the revision of the Compilation of 1680 . On reaching title VII. De los Arzobispos, Obispos y Visitadores Eclesiásticos, in another royal resolution of $7^{\text {th }}$ January 1782 to a consultation by the Board submitted on $10^{\text {th }}$ December 1781 and previously agreed in the $16^{\text {th }}$ session on $3^{\text {rd }}$ of October 1781, two new ministers-members were named, the councillors of the Indies, Francisco Leandro de Viana, I Conde de Tepa, and Juan Manuel González Bustillo; and an auxiliary scribe to the secretary Peñaranda was appointed, Juan Miguel Represa, who had been scribe or penman to the ex-secretary Ayala. They all attended the Board meetings for the first time in the $36^{\text {th }}$ session of $14^{\text {th }}$ January 1782 . Work was slow and onerous, hampered by a reduction in sessions to two hours and two days a week, the numerous occupations of the members-councillors, the constant need to request charters and files from the Secretariats of the Council of the Indies and the concern about the uncompiled legal reforms, but eventually the Board of the New Code got as far as title XIV. De los Religiosos by Ansotegui. However, in the $170^{\text {th }}$ session on $22^{\text {nd }}$ December 1783, the secretary, Peñaranda, was ordered to make draft copies of the laws in accordance with the rulings already set out in the agreements adopted by the Board. This was done so that after the draft copies were revised and approved by the members, a clean copy of them could be made in chronological order. As a result of this decision, they went back to the beginning once again; that is to say, the draft laws, from title I to title XIV, were extended and examined. However, the death of Peñaranda led to the suspension of these compilation operations in the $250^{\text {th }}$ session on $18^{\text {th }}$ May 1785 until a RD of $21^{\text {st }}$ November 1785 led to the appointment of Antonio Porcel as new secretary of the Board, whilst retaining his post as $5^{\text {th }}$ Officer of the Ministry of the Indies. Once they took up their compilation again, the Board made another consultation of $30^{\text {th }}$ March 1787, requesting an increase of one more day a week for the revision sessions and for

\footnotetext{
${ }^{10}$ Actas de las Juntas 4.a y 5.a del Nuevo Código, de 4-VII y 8-VIII-1781 (AGI, Indiferente General, leg. 1.653, ff. 10 r-12 r); y $\mathrm{RI}, \mathrm{II}, 2,15$. Que las causas de gobierno y gracia se resuelvan con la mayor parte, y en iguales se consulte; y para leyes, o derogarlas, concurran las dos partes, y consulta. Asimismo, Muro Orejón, A., El Nuevo Código de las Leyes de Indias. Proyectos de recopilación legislativa posteriores a 1680, tesis doctoral édita, prólogo de Rafael Altamira y Crevea, Madrid, Tipografía de la Revista de Archivos, 1929, pp. 12-22; e Id., "Estudio general del Nuevo Código de las Leyes de Indias», vol. II, pp. 19-22 y 39-40; y Hera, Alberto de la, "La Junta para la corrección de las Leyes de Indias», en el Anuario de Historia del Derecho Español (AHDE), Madrid, 32 (1962), pp. 567-580, en particular, pp. 568-571.
} 
the meetings to be held in the lodgings or house of the Conde de Tepa, "respecto de su proporcionada situación" in order to take advantage of the public holidays. As Carlos III agreed to theses petitions, on clarifying the draft laws from titles XIV to XXIV together with another two new titles added by the Board (the final VIII. De los Esponsales y Matrimonios, and the later XX. De las Vacantes Mayores y Menores de las Iglesias de las Indias) Book I was concluded between April 1786 and May $1787^{11}$.

Once again, the compiling task was suspended after Antonio Porlier, one of the key members of the board, was promoted to Secretary of State for the Universal Office of Grace and Justice of the Indies on $8^{\text {th }}$ July 1787. This meant there were not enough members-councillors even though Carlos III named two new members on the $16^{\text {th }}$ August 1787: José García de León y Pizarro, and Juan Francisco Gutiérrez de Piñeres. Eventually, the monarch himself, in the $\mathrm{RO}$ of $30^{\text {th }}$ March 1788, decided that all the members of the Board: Huerta, Tepa, Bustillo, Pizarro and Piñeres (Agüero and Casafonda had died some time before on $12^{\text {th }}$ January 1782 and $27^{\text {th }}$ November 1785 respectively, and then on $7^{\text {th }}$ May 1788 Domínguez passed away) should constitute a Plenary (or decision-making) Board of the New Code and they would meet once a week or every fifteen days, including public holidays. What is certain is that to be able to carry out the compilation tasks at the desired pace, the sovereign authorized Tepa and Pizarro to form a Particular (or preparatory) Board of the New Code. They would both meet alone in daily sessions, except for holy days of obligation so they could focus on the "prepara- ción, coordinación y arreglo de las leyes nuevas, y calificación de las antiguas". Needless to say, Tepa and Pizarro also had to attend the Plenary Board whose acts were authorised by the secretary Porcel and in his absence, illnesses or other occupations, Represa had been given royal authorisation to "satisfacer los reparos que se ofreciesen y decidir los puntos que se votasen". In compliance with this sovereign resolution, the Conde de Tepa and Pizarro started the preparatory and daily meetings on $14^{\text {th }}$ April 1788. As they were under the pressure of time, and the examination of the laws required their being able to see the previous agreements the Board had made about them, it was agreed that Represa, as authorised substitute scribe-secretary, should draw up an extract of the minutes, which should simply number the laws to be compiled by titles and summarise the agreements with a marginal note of the session they corresponded to.

On $13^{\text {th }}$ September 1788, the Particular Board of the New Code informed Carlos III, who was to die three months later, on14 ${ }^{\text {th }}$ December 1788 , that their task had been concluded, and all that had to be done was to revise the laws compiled, make a clean copy in case of any remaining dissonances or errors, and create an alphabetical index. The monarch's resolution, given in the $\mathrm{RO}$ of $4^{\text {th }}$ October 1788, ordered their Book I with its index to be submitted so that its publication could be decided on. When the new sovereign came to the throne, Carlos IV, the Particular Board again informed about the completion of their mission by means of another consultation of $27^{\text {th }}$ March 1789. As a result, another $\mathrm{RO}$ of $11^{\text {th }}$ April 1789 was issued, stipulating that the Plenary Board

\footnotetext{
11 Actas de las Juntas 6. ${ }^{a}, 16 .^{a}, 36 .^{a}, 170 .^{a}$ y 250. ${ }^{a}$ del Nuevo Código de Indias, de 13-VIII y 3-X-1781, 14-I-1782, 22-XII-1783 y 18-V-1785 (AGI, Indiferente General, leg. 1.653, ff. 12 r-13 r, 27 v-30 v, 76 v-77 v, 285 r-287 v, y 415 r y v). Sin olvidar, definitivamente, a Muro Orejón, A., El Nuevo Código de las Leyes de Indias. Proyectos de recopilación legislativa posteriores a 1680, nota núm. 1, pp. 22-23; e Id., "Estudio general del Nuevo Código de las Leyes de Indias», vol. II, pp. 40-41.
} 
should hold the necessary meetings, including public holidays, to revise the laws agreed by the Particular Board, since the King wanted to see "concluida esta obra, por lo mucho que importaba al Real servicio y a la mejora administración de la justicia en los dominios de las Indias". Obeying this $\mathrm{RO}$ of $11^{\text {th }}$ April and a later one of $5^{\text {th }}$ November 1789 with the same purpose, the Plenary Board completed the revision of Book I with its index on $13^{\text {th }}$ December 1789 , before Jacobo de la Huerta, one of its oldest members, died. Due to a delay by Tepa, Pizarro and Piñeres, and also Bustillo, who was absent because of illness, and despite being initially summarized to just title I. De la Santa Fe Católica., it was not until $2^{\text {nd }}$ November 1790 that the Board made its consultation about the submission of Book I of the New Law Code to Carlos IV for his approval. This would also include a catalogue of the epigraphs of the laws compiled and the citations of their royal charters, with notes and additional notations which indicated whether the law was new, corrected or completely amended. This consultation would also point out the "gravísimas dificultades" that they envisaged for redrafting the remaining eight books of the Compilation, given the variations observed in the functions of the Tribunals and the Royal Treasury in the Indies over time, and in everything related to the areas of commerce and navigation ${ }^{12}$.

After almost a decade and a half dedicated to the Indian compilation, and its well-known interruptions and recommencements, the final royal decision regarding the above-mentioned consultation of $2^{\text {nd }}$ November 1790 was delayed for almost another year and a half. Eventually, the RD of $25^{\text {th }}$ March 1792 was issued and sealed at the Royal Seat of Aranjuez, as a development of a royal resolution of $21^{\text {st }}$ of the same month and year. Surprisingly, Carlos IV and especially his court advisor Antonio Porlier, now Marquis of Bajamar and minister of Grace and Justice of the Indies, decided to authorise the implementation of Book I of the New Code - that is to say it was approved, sanctioned and enacted but not published. Subsequently, the laws of its twenty-six titles became valid regulations with the full force of sovereign authority so that henceforth they would serve as rules and regulations. The laws of the other eight books of the Compilation of 1680 , continued to be in force as long as they were not contrary to those of the Code. What did this special enactment of the unpublished Book I consist of in practice? Carlos IV ordered five authorised copies to be issued, signed by the members of the Board of the New Code, including the RD of $25^{\text {th }}$ March 1792 at the beginning of each one. Three of these copies were given to each of the Courts of the Royal and Supreme Council of the Indies - two for the Government Chambers and one for the Justice Court; the other two were given to the prosecutors of the departments of New Spain and of Peru. What was the purpose of this minimal and select distribution of authorised copies? Well, it was intended that the New Code should be put into practice partially, casuistically and successively. That is to say, for ecclesiastical matters and issues about 'regalías' from the Indian 'Regio Patronato', it would be applied progressively, but this use of the Code would not be made public. The Council of the Indies, heard by the prosecutors, had to apply the laws in all the cases presented, dispatching charters and rulings accordingly. The same process had to be executed through the via reserved for the Ministry of Grace and Justice of the Indies in the resolutions to council consultations and the issuing

\footnotetext{
12 Muro Orejón, A., «Estudio general del Nuevo Código de las Leyes de Indias», vol. II, pp. 40-43.
} 
of royal orders. This Ministry was not expected to be given an authorised copy, probably because the original, presented to the monarch during the Board's consultation of $2^{\text {nd }}$ November 1790, was in Porlier's possession. It was through nine royal charters that up to twelve laws of the New Law Code are known to have been published in America between 1789 and 1804, all of which were new except for one which was substantially modified $^{13}$.

In the above-mentioned RD of $25^{\text {th }}$ March 1792, Carlos IV further determined that it was his sovereign will that the Board should continue its sessions with the zeal and dedication that it was credited with until it had completed its undertaking of this great legislative compilation. He also confirmed the prohibition of any notes or com- ments to the laws of the Indies including those of the New Code, as well as the enforcement of ius interpretandi, having to consult with the Royal Person about any doubts regarding the true and genuine sense of some of these laws, and the difficulties that may arise in their application. Once this RD of $25^{\text {th }}$ March was published by the Board of the New Code in its session of $20^{\text {th }}$ May 1792 , it was simply agreed, in principle, to comply with it. However, a few months later, the Board vigorously questioned it because of the unusual way it was enacted. That is to say, it excluded the publication of the work compiled between 1776 and 1790, so they presented a consultation to Carlos IV, undersigned by three of the members-councillors Tepa, Pizarro and Piñeres dated $8^{\text {th }}$ November 1792 in Madrid, with the dissenting vote of

\footnotetext{
${ }^{13}$ En sus investigaciones entre los fondos documentales del Archivo General de Indias en Sevilla, desde antes de 1929, hasta después de 1979, Antonio Muro Orejón logró hallar cinco Reales Cédulas circulares -más otra, que reformaba una anterior-, a añadir a otras tres ya conocidas, y detectadas por Diego Luis Molinari, nueve en total, que ponían en vigor hasta doce leyes del Nuevo Código de Indias, de ellas, ocho leyes nuevas (L. N.), y una variada sustancialmente (R. V.), en su Libro I, a saber: 1) Real Cédula (RC) circular, datada, en Madrid, el 22-III-1789, que derogaba RI, I, 10, 15, sustituyendo esta ley por la del NCI, I, 7, 12 , relativa a que el conocimiento de las demandas interpuestas por capitales y réditos de Capellanías y Obras Pías, contra legos y sus bienes, no correspondiese a los Jueces eclesiásticos, sino a las Justicias reales. 2) RC circular, despachada en Madrid, de 4-VIII-1790, que mandaba observar NCI, I, 4, 70, sobre el nombramiento de Provisores de los Arzobispados y Obispados de América e Islas Filipinas. 3) RC circular, librada en Madrid, de 15-II-1791, que ponía en vigor NCI, I, 20, leyes 3, 9, 10 y 11, que versaban, respectivamente, sobre la inversión del importe de las rentas de vacantes mayores y menores de las iglesias de las Indias, la remisión de relaciones con el producto de las vacantes y su inversión, la correspondiente justificación de su necesidad que ha de preceder para la asignación económica a las iglesias, y la concesión de lo que fuere regulado justo a los Prelados provistos. 4) RC circular, expedida en Madrid, también de 15-II-1791, que ordenaba cumplir NCI, I, 14, 12, sobre las concesiones de vino, cera y aceite a los conventos e iglesias de los Reinos de Indias e Islas Filipinas. 5) RC circular, extendida en Madrid, de 11-VI-1792, que disponía se guardase $\mathrm{NCI}, \mathrm{I}, 8$, 7, acerca de la licencia que habían de obtener, para contraer matrimonio, los individuos de las Universidades, Seminarios conciliares, y Casas de enseñanza de ambos sexos, que estuvieren bajo la regia protección y Patronato Real. 6) RC circular, signada en San Lorenzo el Real, de 25-X-1795, que ordenaba se procediese, con arreglo a NCl, I, 15, 71, a la hora de conocer y sustanciar las causas por delitos que cometiesen los Regulares. 7) RC circular, fechada igualmente en San Lorenzo, de 29-XI-1796, que imponía la observancia de NCI, I, 15, 38, sobre la incapacidad para testar de los Religiosos de ambos sexos, y también para suceder abintestato, así ellos como sus Conventos. 8) RC circular, suscrita, en Aranjuez, el 29-IV-1804, que modificó la anterior, estableciendo que los Religiosos profesos de ambos sexos, cuando lo eran de Orden Regular que podía poseer bienes, pudieran recibir y gozar herencias, capellanías y demás cosas a las que fuesen llamados. 9) RC circular, despachada en Madrid, de 1-VI-1799, que ordenaba fuesen ejecutadas dos leyes de NCI, I, 24 , 8 y 9, relativa, la primera de ellas, a que se contribuyese, a los Colegios Seminarios, con el 3 por 100 que les estaba asignado; y la segunda, a que no fuere invertida, para otros fines, la cuota señalada a los Seminarios [Molinari, D. L., Introducción al vol. VII de los Documentos para la Historia Argentina, Buenos Aires, Facultad de Filosofía y Letras, 1916, pp. LXXXII- LXXXIII; y Muro Orejón, A., "Estudio general del Nuevo Código de las Leyes de Indias", vol. II, pp. 51-52; ld., El Nuevo Código de las Leyes de Indias. Proyectos de recopilación legislativa posteriores a 1680, pp. 35-36; e Id., "Leyes del Nuevo Código de Indias vigentes en América», en la Revista de Indias, Madrid, V, 17 (julio-septiembre, 1944), pp. 443-472].
} 
Bustillo dated $6^{\text {th }}$ November. The former three members realised that Carlos IV's reluctance to apply Book I and his preference for doing so privately and secretly, was founded on the "novedad que podían acusar algunas de sus leyes". In order to remove this distrust, the Board presented the King with three types of provisions: the laws already compiled (R.), extracted from the 1680 Compilation and without any new changes; the post compilation laws, but substantially modified (R.V.), which were already observed in the New World; and the completely new laws, (L.N.), formed by the general principles of Law and taken from the 'regalías' of the Crown in the Indies. It was only in these neo-coded laws, which were the fewest in number, that the Board admitted "algún terror o recelo de novedad". However, it made it clear that as a constant principle of Law, the enforcement of a law could only be invoked from the moment of its publication, which constituted an essential formality and requirement. For this reason, the board was afraid that there would be two legislations: a public one, the 1680 compilation, which the judges and vassals of the Indies ruled by; and another secret and private one, the 1792 Code, reduced to the narrow limits of the Royal Council of the Indies (its two Government Chambers and its Justice Court, its two Public Prosecutors, its three Secretariats, Accounting Office ) and the Secretariat of State and of the Office of the Indies (and other Ministries, such as those of Treasury and War), where the ministers-councillors could not read or study the laws outside the seat of the court. The fact that the New Code was not published caused the Council and Ministry of the Indies, governed by its laws, to take offence "el derecho y la justicia de muchos vasallos que, habiendo promovido sus acciones según las leyes de la Recopilación o Cédulas posteriores, se hallarían con resoluciones contrarias, multiplicándose los recursos, de los que se ocuparían los tribunales, con grave perjuicio para los interesados". However, in a conciliatory move, the Board of the New Code proposed that the King should deign to authorize it, especially so that he could be consulted successively about the new laws of the Code. In this way, on issuing the Royal Charters resulting from the royal resolutions adopted in the light of such consultations, the desired goal of the publication of Book I would shortly be indirectly, although partially, achieved. In any case, although Bustillo did not participate in the formulation of the main consultation of $2^{\text {nd }}$ November 1790 due to illness, his dissenting vote of $6^{\text {th }}$ November 1792 made it clear that he was in favour of strict compliance with all aspects of the RD of $25^{\text {th }}$ March 1792. In spite of such a dissenting vote, the majority of the Board of the New Law Code, that is to say Tepa, Pizarro and Piñeres, insisted on their initial opinion, arguing that once the sovereign had seen that all the laws from Book I were arranged by reason and justice, it would be "ocioso e impertinente" to concern themselves about whether or not the laws compiled in 1680 should continue to be regarded ${ }^{14}$.

Unlike the first consultation by the Board of

\footnotetext{
${ }^{14}$ AGI, Indiferente General, leg. 546; AGI, Indiferente General, leg. 1.653, ff. 425 r-428 r; y Muro Orejón, A., El Nuevo Código de las Leyes de Indias. Proyectos de recopilación legislativa posteriores a 1680, pp. 31-34; e Id., "Estudio general del Nuevo Código de las Leyes de Indias», vol. II, pp. $44-49$ y 61-63. Según este mismo autor, en una hoja de papel que sirve de carpeta a una copia del RD de 25-III-1792, hallada, por él, en el Archivo General de Indias, de Sevilla, en el legajo 663, de su sección de Indiferente General, se lee: «Decreto disparatado en tiempo del Marqués de Bajamar, sobre el nuevo Código de Leyes de Indias, que no se ha publicado y quiere que se observe» [Muro Orejón, A., "Leyes del Nuevo Código de Indias vigentes en América", nota núm. 3, p. 444].
} 
the New Law Code of $2^{\text {nd }}$ November 1790, which took almost a year and a half to be resolved, this second consultation of $8^{\text {th }}$ November 1792 would take as long as almost seven years, until $7^{\text {th }}$ July 1799, when Carlos IV decided to cease the Board's commission of drawing up a Code of Laws of the Indies, and substituted it with a unipersonal entity, entrusting it to Antonio Porcel, secretary of the Board for fourteen years. In truth, the change from being a Board consisting of a group of members to a unipersonal entity consisting of its secretary, flagrantly contradicted the provisions of the RD of $25^{\text {th }}$ March 1792, where the monarch had urged the Board to conclude their great work of the legal compilation and address the revision of the remaining books of the New Law Code. But it is also true that with the death of Bustillo in 1797 and Pizarro's death in 1798, the Board was reduced to only two members, Tepa and Piñeras. It is evident that rather than appoint new members to the Board, and by dissolving it de facto and stripping it of its single principle function the sovereign had preferred to entrust all the responsibility of the compilation in someone like Porcel, who, besides being its secretary, was also secretary of the Council and Royal Chamber of the Indies. This would facilitate his consultation of all the documents related to the matters to be compiled, archived in the Royal and Supreme Council: government cases, civil lawsuits, criminal cases, charters, provisions, court decisions, orders, investigations, ordinances, resolutions, judicial orders and representations.

The Council of the Indies itself agreed with the Board through the consultation by the plenary of the three chambers of Government and Justice on $26^{\text {th }}$ April 1794. It noted that non-publication of the law essentially undermined its very existence, which could only be rectified by publishing and distributing its regulatory text, so that it should be known by those who had to comply with it and observe it, that is to say, the governmental authorities and the justice courts of the New World: "Aunque la ley esté decretada y mandada promulgar por el Príncipe, y aunque llegue privadamente a noticia de los vasallos, no obliga a éstos mientras no se ha ejecutado la promulgación solemne; y ésta es la doctrina común en la materia, así en la jurisprudencia Romana como en la de nuestro Reino, y en la Canónica". In the same sense, it added that as with the Compilation of 1680, the New Code had to also be made public, through the publication and distribution of its text. Further to this, the Council claimed its supreme consul-

Con el auxilio interpretativo de Tau Anzoátegui, Víctor, "Acerca de la elaboración y publicación de la ley en el Derecho Indiano», en AHDE, Madrid, 80 (2010), pp. 157-181. En general, de este autor, Casuismo y Sistema. Indagación histórica sobre el espíritu del Derecho Indiano, Buenos Aires, Instituto de Investigaciones de Historia del Derecho, 1992; y Coronas González, Santos Manuel, "La ley en la España del siglo xviii», en $A H D E, 80$ (2010), pp. 183-242. Sobre la ley, y su naturaleza histórico-jurídica, Álvarez Cora, Enrique, "La noción de la ley castellano-indiana», en Manuel Torres Aguilar (coord.), Actas y Estudios del XV Congreso del Instituto Internacional de Historia del Derecho Indiano, 2 vols., Córdoba, Universidad y Diputación, 2005, vol. II, pp. 1287-1312; e Id., "Leyes y juicios en Castilla: A favor de la potestad legislativa del Rey y contra la cultura jurisdiccional», en Initium. Revista Catalana d'Història del Dret, Barcelona, 13 (2008), pp. 587-638. Sobre la misma materia, García-Gallo, A., "La ley como fuente del Derecho en Indias en el siglo xvi», en AHDE, Madrid, 21 (1951), pp. 607-730, luego en sus Estudios de Historia del Derecho Indiano, Madrid, Instituto Nacional de Estudios Jurídicos, 1972, pp. 169-285; Rico Linage, Raquel, «Publicación y publicidad de la ley en el siglo xviii: la Gaceta de Madrid y el Mer-curio Histórico-Político», en AHDE, 57 (1987), pp. 265-338; Tau Anzoátegui, V., "La noción de ley en América Hispana durante los siglos xvi a xviii», en su colectánea sobre La Ley en América Hispana. Del Descubrimiento a la Emancipación, Buenos Aires, Academia Nacional de la Historia, 1992, pp. 27-48; e Id., "Entre leyes, glosas y comentos. El episodio de la Recopilación de Indias", en el Homenaje al Profesor Alfonso García-Gallo, 5 vols., Madrid, Editorial Complutense, 1996, t. III, vol. I, pp. 267-283; Lorente Sariñena, Marta, La voz del Estado. La publicación de las normas (1810-1889), Madrid, CEPyC, 2001; y Rico Linage, R., "Promulgación o publicación: la voz del legislador en el primer constitucionalismo (1808-1823)», en AHDE, 75 (2005), pp. 1013-1035. 
tative and legislative authority, considering that it must revise the contents of the New Code before it could be published. As a corporation, it also regretted that once the RD of $7^{\text {th }}$ September 1780 had authorised the Board to consult the sovereign directly, the Council had not participated at all in examining, discussing, drafting and drawing up Book I. The royal resolution, also dated $7^{\text {th }}$ July 1799 -published in the Council on the $9^{\text {th }}$, in the Board of the New Code on the $11^{\text {th }}$, and received by its president, the Conde de Tepa on $15^{\text {th }}$ July 1799- to the consultation by the Plenary Council of the Indies of $26^{\text {th }}$ April 1794, adopted similar but more expressive and explicit terms than in the Royal Resolution of $7^{\text {th }}$ July 1799 to the second consultation of the Board of $8^{\text {th }}$ November 1792:

“Quiero que D. Antonio Porcel se encargue de la reforma de la Recopilación de Indias, y que, concluida, la presente al Consejo, para que este Tribunal informe lo que se le ofrezca y parezca. Se pasará a Porcel el Libro primero del Nuevo Código, cuya sanción no está publicada, y asimismo todos los demás trabajos y papeles concernientes, para que le sirvan en dicha reforma, subsistiendo sólo, por ahora, las leyes del referido Libro primero que se hayan mandado observar por Cédulas circulares y las demás que sea preciso hacer observar por el mismo medio, entretanto se concluye la obra encargada y merece mi aprobación".

It seems evident that, this second Royal Resolution by Carlos IV of $7^{\text {th }} / 9^{\text {th }}$ July 1799 , in the aftermath of the Ancien Régime, meant the affirmation of the old principle of the publication of the laws. Along with the indirect acknowledgement of the traditional doctrine sustained by the Council of the Indies, its claim was accepted, and it would be able to revise corporately the new project of the Code of the Indies, once the factitious dissolution of the Board of the Laws of the Indies was decreed. It is clear that there was a desire to amend an error committed prior to $25^{\text {th }}$ March 1792. On the other hand, Antonio Porcel, was not just single compiler of the Indian legislation, from the $7^{\text {th }}$ and $9^{\text {th }}$ July 1799 , but he was also named Commissioner or commissioned reformer of this legislation with limited authorization, competences and functions compared to the Board of the New Code, of which he became no more than a simple unique and universal heir. Entrusted with the reform of the 1680 Compilation, he was not expected to continue with the task undertaken by the Board, twenty-three years before. Of course, nothing prevented Porcel from clearly reforming the whole of the 1680 Compilation, including its Book I, which corresponded to Book I of the New Code, since the laws, in the latter Book, that had been ordered to persist through Royal Charters, and were issued in the past or were to be dispatched in the future, would only be laws for now. One evident ambiguity stood out, since the Royal Resolution of $7^{\text {th }} / 9^{\text {th }}$ July 1799 would undoubtedly allow the monarch, Carlos IV, and his Council of the Indies as well as his minister of Grace and Justice, José Antonio Caballero, to be free to decide, when the time came, which Book I of the New Code they wanted to rule when Porcel concluded the reform of all the books in the future. This hypothesis would never be verified, since, in 1803, Porcel would only present Carlos IV with Book I, drawn up by the extinct Board of the New Code, which had simply been added to with royal provisions issued subsequent to 1791. According to Juan Miguel Represa, Porcel had done this by using the collection of charters that he (Represa) had gathered in accordance with the $\mathrm{RO}$ of $10^{\text {th }}$ 
April 1794, which had entrusted him to continue with the collection of charters by Manuel José de Ayala, by aggregating subsequent resolutions ${ }^{15}$.

Nothing further is known about the New Code of the Indies until the end of the war of Independence (1808-1814) and the absolute monarchy was restored, after the RD issued in Valencia on $4^{\text {th }}$ May 1814. When Fernando VII was returned to the throne, it was not long before the old 'Carolina'16 Board was newly restored as the Ferdinand Board for the legislation of the Indies, although it would later be thwarted. The petition to resume the interrupted new compiling task reached the Council of the Indies in the form of a Presentation signed by the former scribe of the Committee of the New Code Juan Miguel Represa in Madrid on $10^{\text {th }}$ June 1815. On $16^{\text {th }}$ March 1816, it was decided that they were to continue with the work on the Code, and to re-establish the figure of the Commissioner compiler, in which case, the Plenary Council of the Indies initiated a consultation on $19^{\text {th }}$ December 1816 . Its purpose was to ensure the briefness and success of the final preparation of a complete New Code and for it not to be limited to its Book I. It also proposed the adoption of several legislative measures to the monarch: the restoration of the former Board, comprising only three ministers-councillors and not five as before, and a secretary, whose task would be exclusively dedicated to writing up the New Code during the days and times of the tribunal, in a room allocated to him by the president in the Council of Indies. The main occupation of the revived Board would be to draft a general plan divided into books and titles, subsequently ordering the laws to be included in each title and publishing them by means of royal charters for all the American territories. Once they were all revised and approved by the Council and approved by the King, this would facilitate and ensure the prompt completion of this Indian compilation. The Board would then have the exclusive competence of settling the doctrinal disputes raised by the critics and interpreters about the laws already compiled or those to be compiled, so that "la muchedumbre de pleitos que se muven a la sombre de sus discordantes opinions, en materia de contratos, mayorazgos, testamentos, y otras de iguale nauraleza". In attention to Represa's achievements, after almost thirty-five years of service, he would be appointed secretary of the Board with authorisation to request a clerk or scribe from each of the two Secretariats and Accounting Offices of the Council. In the Royal Resolution to this synodal consultation of $19^{\text {th }}$ December 1816, Fernando VII agreed to all parts except in matters related to expenses, so on $14^{\text {th }}$ January 1817 the Plenary Council of the Indies published: "Como parece no habiendo aumento de sueldos". However, as the appointment of the ministers-councillors for the restored Fernando Board of the legislation of the Indies was pending, and also at Represa's request, the Plenary Council of the Indies had to remind the sovereign of this through another consultation of $12^{\text {th }}$ May 1817. Consequently, Fernando VII appointed Francisco Ibáñez de Leiva, Antonio Martínez de Salcedo and Francisco Xavier Caro on $12^{\text {th }}$ January 1818. Almost two years later, com-

\footnotetext{
15 AGI, Indiferente General, leg. 565; AGI, Indiferente General, leg. 1.653, ff. 429 r-430 r; Muro Orejón, A., "Estudio general del Nuevo Código de las Leyes de Indias", vol. II, pp. 49-51, con el texto de la Real Resolución de 9-VII-1799, en p. 50 in fine, de donde procede la cita literal antecedente; Id., "Leyes del Nuevo Código de Indias vigentes en América", pp. 445-446; e Id., El Nuevo Código de las Leyes de Indias. Proyectos de recopilación legislativa posteriores a 1680, pp. 34-37; y Tau Anzoátegui, V., "La formación y promulgación de las leyes indianas. En torno a una consulta del Consejo de Indias en 1794», en La Ley en América Hispana. Del Descubrimiento a la Emancipación, pp. 145-171.
}

${ }^{16}$ Carolino refers to anything related to any of the kings called Carlos, especially Carlos V. 
municated by a RO of $26^{\text {th }}$ December 1819 , another three were added: José de Navia Bolaños, Bruno Vallarino and Manuel de la Bodega. In this same RO of 1819, Fernando VII ordered the Board to inform him about the state and progress of the work on the Code, and that they should do so every month. In spite of this initial resolution, the monarch did not observe the first measure proposed in the consultation of $19^{\text {th }}$ December 1816, as there were six and not three members chosen for the Legislation Board ${ }^{17}$.

Since the Presentation by Represa of $10^{\text {th }}$ June 1815 , four and a half years had been wasted on all these preliminaries, but finally the first session of the restored Board of the Legislation of the Indies was held on $19^{\text {th }}$ January 1820. Paradoxically, it was after the liberal military uprising by Rafael del Riego had taken place on $1^{\text {st }}$ January 1820, in the Sevillian town of Las Cabezas de San Juan: the beginning of the so-called Constitutional or Liberal Triennium (1820-1823). Only three members of the Board attended this constitutive meeting, which was merely preparatory, they were: Leiva, who was President, Navia and Bodega. It was agreed that Represa should send a notification to the Secretariat of Peru of the Council of Indies, reclaiming the prompt submission of the dossier containing the minutes taken since the attempted creation of the Code up to the current time, and that, once received, it should be opened up to continue noting down the minutes. In the second session, on Monday $24^{\text {th }}$ January 1820 , with Leiva, Navia, Vallarino and Bodega in attendance, Represa was able to make a detailed list of the main consulting and regulatory milestones that had taken place in the process of drawing up the
Code. An agreement was reached that the president, Leiva, should be the one to send a notification to the Ministry of the Indies, to report that only Book I had been approved, and that there was a legislative Collection, gathered by the secretary, Represa, which contained provisions and resolutions dated up to 1819. On the other hand, when the 'Carolina' Board of the New Code had been dissolved, the minutes for the sessions held between 1785 and 1799 together with other related papers had disappeared and had been deposited in the Ministry of the Indies in the times of Joseph I Bonaparte and the invading Napoleonic Government. Some documents that had not been delivered to the president, Leiva, did not arrive until three weeks later in compliance with a $\mathrm{RO}$ of $20^{\text {th }}$ February 1820. A week before, however, on Sunday $13^{\text {th }}$ February 1820, the third meeting of the Board of Legislation, the last one under the rule of Fernando VII, had taken place. It was the last one in which they would discuss the failure of the unfinished Code of the Indies, which would now no longer be mentioned and would be almost forgotten. Five members were in attendance: Leiva, Caro, Navia, Vallarino and Bodega, who simply deliberated about how the general plan of the Code could be drawn up, divided into books and titles. After drawn out conferences, it was unanimously agreed that the members, Navia and Bodega, should be the ones to consider and prepare this plan. Once its preliminary stages were completed, it had to be examined and rectified by the Board. In a first annex to the minutes, Represa clarified that the missing original minutes from 1785 to 1799 of the extinct Board of the New Code, and Book I, the version by An-

\footnotetext{
${ }^{17}$ AGl, Indiferente General, leg. 1.653, ff. 417 r-418 r, y 439 r y v; y la Consulta del Consejo Real de las Indias, para la continuación del Código. Madrid, 19-XII-1816 (AGI, Indiferente Feneral, leg 1.653, ff. 431 r-436 r). Figura resumida en Muro Orejón, A., EI Nuevo Código de las Leyes de Indias. Proyectos de recopilación legislativa posteriores a 1680, pp. 38-50; e Id., " Estudio general del Nuevo Código de las Leyes de Indias», pp. 53-56. La Exposición, dirigida al Consejo Real de las Indias, de Juan Miguel Represa, de 10-VI-1815, en AGI, Indiferente General, leg. 1.653, ff. 431 r-433 r.
} 
tonio Porcel presented to Carlos IV in 1803, had been submitted through a reserved via. They had been obtained along with the preceding minutes from 1776 to 1785 by one of the two members, Manuel Bodega, commissioned to draw up the plan. In a second annotation of $7^{\text {th }}$ June 1820 , Represa stated that he had obtained all the referred to papers in Bodega's possession ${ }^{18}$.

In this brusque and abrupt way, the brief and incipient minutes of the Fernando $\mathrm{V}$ Board of Legislation ended, and along with them, the life, almost the whole project of the New Code of Laws of the Indies. During the Liberal Triennium, the Council of the Indies, as all the Royal CounciIs was dissolved by virtue of a RD of $12^{\text {th }}$ March 1820. Although it was re-established in 1823, the Board was not, so the New Code which was no longer so new remained relegated to complete ostracism. It should be remembered that the Indies of the $16^{\text {th }}$ and $17^{\text {th }}$ century, or $18^{\text {th }}$ century, America at that time literally consisted of only three islands, or two islands Cuba and Puerto Rico, and a distant Asiatic archipelago, the Philippines. Hardly anything of the Indies remained for any old or new Code. The work by the two commissioner members, Navia and Bodega, entrusted with drawing up a general compilation plan, is otherwise unknown. There is no evidence that they managed to work on it, or even if they had time to make a draft. It can be ventured, with little margin for error, that if such a draft had existed, the Board would not have been able to examine it, and even less so the Council of the Indies, since neither had the monarch's approval. There is, on the other hand, complete certainty that, unlike his father and predecessor on the throne Carlos IV, Fernando VII had the clear intention of eventually publishing the New Code of the Indies. Through a $\mathrm{RD}$ of $25^{\text {th }}$ December 1819, he ordered the 1680 Compilation to be reprinted as soon as possible, so the Code was revealed to the public because of "carecer de su instrucción los magistrados, a causa de la falta de ejemplares, y se facilite su repartimiento a todas las autoridades de Ultramar". In view of this royal provision the Plenary Council of the Indies made some observations to the King through a consultation of $17^{\text {th }}$ February 1820, which showed the numerous drawbacks making it inadvisable to reprint it, without additions or annotations of any type, despite the century and a half that had gone by since 1680. In any case, it was not going to constitute an effective antidote against the revolutionary independence movement that was spreading through America, since many of the revolutionary leaders were counsels and lawyers, like Miguel Hidalgo, the priest from Dolores, whose knowledge of the Indian laws had not held him back in his armed rebellion against the Crown. However, nothing stopped Fernando VII form determining, on $8^{\text {th }}$ March 1820 that "Quiero que se haga la reimpresión de la Recopilación, con la adición que propone el Consejo"19. An addition that would mean adding to the Compilation of 1680 some of the main corpora of the subsequent Indian regulations that had been enacted: the Ordenanzas de Intendentes of 1764 and the intendenciales generales of 1803; the Ordenanzas de los Consulados of Mexico 1603-1604 and Lima 1627; or the Instrucción de los Regentes of the Royal Audiences of 1776 ,

\footnotetext{
${ }^{18} \mathrm{AGI}$, Indiferente General, leg. 1.653, ff. 437 r-446 v; y Muro Orejón, A., El Nuevo Código de las Leyes de Indias. Proyectos de recopilación legislativa posteriores a 1680, pp. 44-47; e Id., "Estudio general del Nuevo Código de las Leyes de Indias», vol. II, pp. 55-56.

${ }^{19}$ Tanto el RD de 25-XII-1819, como la ulterior, y consiguiente, consulta del Consejo Pleno del Real y Supremo de las Indias, de 17-II-1820, han sido parcialmente transcritos, en sus apartados fundamentales, por Muro Orejón, A., El Nuevo Código de las
} 
etc. In the end, the monarch's wishes could not be met; neither the 1680 Compilation was officiaIly reprinted during the reign of Fernando VII, nor was the 1792 New Code printed, not even the ecclesiastical and 'regalista' Book I.

\section{THE CONTENTS OF THE NEW CODE OF THE INDIES: MORE OB- SERVATIONS AND ITS NECESSARY REVISION.}

The Board of the New Code of the Indies, a central political-administrative body of the Hispanic Monarchy in the Early Modern Age, was a minor corporation compared to the Royal Councils of the Monarchy, integrated by few people and dedicated to studying the more specific and concrete issue of the Indian legislation. The Board was also a circumstantial and episodic entity which disappeared once it had fulfilled its royal mission, although its first stage would last almost a quarter of a century, between 1776 and 1799, under the reigns of Carlos III and Carlos IV. It was then replaced by a commissioner for the new code, or better said an individual compiler, Antonio Porcel; followed by a second stage of five years, from 1815 to 1820 , when Fernando VII ruled. It was not therefore an ordinary or permanent Board, characterized by its stability, its independence and equality with the councils, directly related to the King without any intermediary. as was the case, among many others, of the Royal Boards of War of the Indies and Treasury of the Indies. Of course, it was far from a supreme Board of the gene- ral government of the Monarchy, situated above the Councils, alongside the monarch to supervise all the matters like the so-called Supreme Board of State, created in 1787 by Carlos III as proposed by his secretary of the Office of State, the Count of Floridablanca. The Board of the New Code was an extraordinary special, temporary or ad hoc Board, conceived to solve a determined issue, and hence once its activity came to an end, it was headed for extinction. However, its limited duration would span up to three decades. Its sta$\mathrm{ff}$, the appointment of its members and its competences, were established by the same regulation that constituted it, as usual a Royal Decree, in this case that of $9^{\text {th }}$ April 1776. It was an advisory entity and not executive, whose functions in the development of its activity were not exclusive or subject to special rules, which was the case with the ordinary Boards. It did not comprise members who were ministers-councillors of different Royal Councils, as occurred with other Boards, but by members of the very Council of the Indies. In fact, it should be remembered that this synodal entity distrusted this Royal Board, objecting to it for denying it fundamental legislative consultative competence, although its resistance would not amount to much, undoubtedly because the Board was formed exclusively by councillors of the In$\operatorname{dies}^{20}$

The work method followed by the Board of the New Code was based on the project drawn up by the first commissioned compiler, Juan Crisóstomo de Ansotegui, between 1776 and 1789 for Book I. It is known that this book, which was one

Leyes de Indias. Proyectos de recopilación legislativa posteriores a 1680, pp. 44-50; e Id., "Estudio general del Nuevo Código de las Leyes de Indias", vol. II, pp. 55-58. Además de los Decretos de la Reina Nuestra Señora Isabel II, dados en su Real nombre por su Augusta Madre la Reina Gobernadora, y Reales Órdenes, Resoluciones y Reglamentos generales expedidos por las Secretarías del Despacho Universal desde primero de enero hasta fin de diciembre de 1834, por Don Josef María de Nieva, de Orden de S. M., t. XIX, Madrid, Imprenta Real, 1835, pp. 158-166; y Dios, Salustiano de, Fuentes para el estudio del Consejo Real de Castilla, Salamanca, Diputación, 1986, doc. núm. XXXV, pp. 168-169. 
of the nine of the 1680 Compilation of the Indies, was the only one executed, reformed and approved by Carlos IV in 1792. Ansotegui had drawn up his Book I using the regulatory materials supplied by the archive at the Royal Council of the Indies and above all by Manuel José de Ayala's Cedulario $^{21}$. This was a chronological collection of the royal resolutions, decrees, charters and provisions issued by the monarchs subsequent to 1680 . To avoid complications and innovations, which he believed would not be welcomed by the Council, or even by the Secretary of State and the Office of the Indies, Ansotegui structured his compiling work by taking Book I of the 1680 Compilation as a reliable model. He followed the same design, including 24 titles that were practically identical to those in the former publication. As in the Compilation, the sovereign's authorisation was noted in the margin next to each law, followed by the place and the date on which his royal provisions had been issued. Each title and each law was headed by an epigraph to briefly outline the content. Subsequently, Ansotegui collected formerly compiled laws still in force, with or without any slight modification or variation, to which he added uncompiled royal provisions and resolutions issued after 1680. He also drew up new laws that responded to post-compilation provisions about matters that were not included in the printed Compilation or that abrogated some of its precepts or did not have a precedent, and therefore required a subsequent royal sanction.

In 1929, in his doctoral thesis about the subject, Antonio Muro Orejón, adopting the explicit criticisms of the ministers-councillors of the New Code, did not hesitate to discredit the work by Ansotegui for its extraordinary pomposity, excessive exordiums or preambles, lack of authority, unnecessary repetition of the same matter in different laws, systematic and unjustified alteration of the terms employed in the laws compiled and printed in 1680, citation errors regarding the charters and royal provisions noted in the margin of the laws, created to indicate their origin, etc. There is ultimately no greater disavowal of a work of compilation, which since its origins had already been undermined by the constraints of vices, which, if not insurmountable, were a very strong impediment to the compilation venture coming to fruition. Particularly discredited was its initial work method, based on one or two commissioned compilers, chosen from outside the select nucleus of jurists that comprised the Royal Council of the Indies. Moreover, the commissioners did not even come within the realms of this nucleus of power and legal knowledge but came from the bureaucratic world of officials and public agents of the Indian Administration. They were appointed in an intentionally balanced way, one from the secretarial or ministerial offices and the other from the council

\footnotetext{
20 Baltar Rodríguez, Juan Francisco, Las Juntas de Gobierno en la Monarquía Hispánica. (Siglos xvi-xvii), Madrid, CEPyC, 1998, pp. 617-766. Amén de Sánchez González, Dolores del Mar, El deber de consejo en el Estado Moderno. Las Juntas "ad hoc" en España (1474-1665), Madrid, Polifemo, 1993; e Id., Las Juntas Ordinarias. Tribunales permanentes en la Corte de los Austrias, Madrid, Universidad Nacional de Educación a Distancia, 1995; y Valero Torrijos, Julián, Los Órganos Colegiados. Análisis histórico de la colegialidad en la organización pública española y régimen jurídico-administrativo vigente, Madrid, CEPyC e Instituto Nacional de Administración Pública, 2002. Y de Escudero, José Antonio, "El Rey y el gobierno central de la Monarquía en el Antiguo Régimen», en J. A. Escudero (ed.), El Rey. Historia de la Monarquía, 3 vols., Barcelona, Fundación Rafael del Pino y Editorial Planeta, 2008, vol. I, pp. 315-380 y 442- 450; e Id., Los hombres de la Monarquía Universal, Madrid, Real Academia de la Historia, 2011, pp. 21-23 y 115-116.

${ }^{21}$ Cedulario is a collection of royal charters.
} 
office: Miguel José Serrador, was second official of the Ministry of the Indies; and Juan Crisóstomo de Ansotegui, was fiscal agent of the Council of the Indies ${ }^{22}$. It seems that with the RD of $9^{\text {th }}$ May 1776 for the appointment of both compiling commissioners, Carlos III had preferred to assign the task to mere automated collectors of laws. They would carry out a purely and unquestionably technical task, foreseen to facilitate the real or authentic compilation work that would lay with the ministers and magistrates comprising the Board of the New Code, the only ones with the faculties to debate and deliberate about royal regulatory policy, in this case Indian. Hence, the always pro domo sua and unfair criticisms voiced by the members of the Board in their acts against Book I by Ansotegui seem excessive and biased.

In the sessions of the new coding Board, its members began with an identical modus operandi, to be revealed later by Muro Orejón. They started with a careful reading of the law to be dealt with, verifying whether it was old or compiled in 1680, or new and not yet compiled. If it was an old law, it was observed whether it had been modified and included in the Indian compilation or not, and at the same time, whether the modification was fundamental or merely incidental. When the Ansotegui law being examined consisted of the reproduction of a law already compiled, but slightly or incidentally changed (R.), in other words, presented a certain variation in terms or "inversión de algunas cláusulas y palabras"-, in this case the Board adopted the criterion that the compiled law would prevail instead of the projected law. It was generally understood, that the former had simplicity, dignity and strength in its style and expression which suited the matter, avoiding thereby the irreparable drawback of the latter which distorted the context and the wording of some "leyes consagradas por el tiempo y la observancia, y estampadas con determinadas palabras en las obras de muchos sabios escritores". If the Ansotegui law under revision was an old one, also compiled but substantially modified (R. V.), that is to say altered, added to or partially abrogated by one or more of the laws subsequent to 1680, the Board read it carefully to determine which part had been changed. This examination was verified by certifying a law irrefutably with the royal provision it proceeded from so as to appreciate its degree of identity, any alteration made and the legal reason for its inclusion in Book I of the New Code of the Indies. Here, Ayala's Cedulario was particularly useful, since he had organised the provisions subsequent to the 1680 Compilation in a chronological order. If Ayala's Cedulario did not include the origin of the law -and although it did so elsewhere, this Cedulario lacked all legal value because it was a simple private compilation, only useful as a source of information-, the Board requested it to be submitted and transferred to them from the official books of charters kept in the Secretariats of New Spain and of Peru of the Royal Council of the Indies. It had to be accompanied by as many files, consultations, bundles and other documents and papers that would help them to have a better knowledge of the matter. Attention was given to whether the words used by Ansotegui when drawing up his projected law responded in form and grammati-

\footnotetext{
22 Muro Orejón, A., El Nuevo Código de las Leyes de Indias. Proyectos de recopilación legislativa posteriores a 1680, pp. 23-25. El único ejemplar del que se tiene noticia, hasta ahora, del Libro I, de Ansotegui, se halla incompleto, puesto que consta de 268 folios, recto y verso, pero carece de los títulos I y XV a XXIV, y de las primeras seis leyes del II, o sea, de casi la mitad de la obra. Hallado por Juan Manzano Manzano, se custodiaba, antes de 1936, en AGI, Indiferente General, leg. 1.563 A; habiéndose procedido, con posterioridad, a su traslado de ubicación archivística, siendo su actual signatura la de AGI, Mapas y Planos, Libros Manuscritos, núm. 25
} 
cal, logical and legal concept to the authority, dignity and the greatness that should emanate from a royal provision.

The agreement of the Board was adopted unanimously or by a simple majority of its members and consisted of approving the modified law or rejecting such a variation, indicating in the latter case the way in which this change or alteration should be carried out. In third place, if the law contributed by Ansotegui was new, that is to say not included in the $17^{\text {th }}$ century Compilation of the Indies, as a precept issued by Carlos II (after 1680), Felipe V, Fernando VI or Carlos III (L. N.), it was carefully read in the same way as the previous ones. It was then certified with the royal resolution from which it proceeded in order to verify its identity and correspondence. All the files and consultations that could enlighten the Board's examination were transferred, and all the details about how the law was drawn up and its concept were thoroughly analysed, then finally the members voted in favour or against it. If they voted against, then they would have to indicate how the law should be rewritten. Finally, if the law in question was one of the very few that Ansotegui had allowed himself to propose, without counting on the support of any royal resolution or provision to base it on, then this very new law was read and revised with greater meticulousness. In all cases, these laws were either rejected because they were considered unnecessary, audacious, and detrimental, since they had serious drawbacks, or they ended up being reformed so much in essence that rather than being Ansotegui's regulatory project, it would be the new coding Board's. In any case, the agreements adopted corporately, especially those contrary to the projected laws by Ansotegui, were substantiated by the Board, and briefly recorded in the minutes along with the individual votes of the dissenting ministers ${ }^{23}$.

Book I of the New Code presented by Ansotegui in 1780 was reiterative and the same matter appeared in different laws unnecessarily, increasing their number. The Board always preferred concision, including various laws referring to the same matter in one law. Once the content of the law was examined, the rubrics were studied to see whether they corresponded or not. If the rubric corresponded to the content, it was approved; if not, the pertinent amendment was introduced. Once the laws and rubrics of each title were approved, they considered the accuracy of the overall rubric. In most cases, the renowned titles of the 1680 Compilation were respected, but some corrections and alterations were also made. The Board also gave special attention and dedication to the marginal references of each law which recorded the monarch legislator, and the date and place of the enactment of the royal resolutions that legally validated these laws. The Board continually corrected the careless mistakes they often noticed in the work by Ansotegui regarding the names of the kings, the places and the days, months or years. In the minutes of the Board of the New Code of the Indies, there are many references to the debates between the members about the issues dealt with in each

\footnotetext{
${ }^{23}$ Muro Orejón, A., El Nuevo Código de las Leyes de Indias. Proyectos de recopilación legislativa posteriores a 1680, pp. 25-27; Id., "Las leyes nuevas del Nuevo Código de Indias", en Mercurio Peruano, Lima, XXXV, 333 (1954), pp. 995-1013; e Id., "Estudio general del Nuevo Código de las Leyes de Indias", vol. II, pp. 22-24
} 
session. Some of these cases are recorded extensively regarding particular disputes, usually confrontations about 'regalía' issues, and mainly involved Casafonda, Porlier and Tepa, who displayed their erudite doctrinal knowledge. As they were revising the Ansotegui laws, the successive agreements adopted by the Board were disseminated in the minutes of the sessions held. However, in the $108^{\text {th }}$ session on $13^{\text {th }}$ January 1782 , at a very advanced stage of the compiling process, Porlier proposed that the new laws should be redacted in accordance with what had already been agreed so that the members of the Board could verify it the wording and determine whether it required some correction. If this measure was not taken, Porlier was afraid that in the near future nobody would be able to "entresacar, de las actas, el verdadero y genuino dictamen, y acuerdo de la Junta de Leyes, sobre cada una». The Secretariats of New Spain and Peru of the Council of Indies took a long time to search for, find and provide the charters, files and consultations that the Board requested, so in order not to detain the rhythm of their work they continued examining other laws, so many were delayed and pending. It came to the point where laws that should follow one after the other were examined and revised completely separately in time. For this reason, Porlier, being practical, announced that they should throw away the laws as they were adopted. If this was not done, the secretary of the Board, Luis Peñaranda, should draw up an analytical summary from the minutes of the sessions already held and those being held, where "puntualmente se fuesen reuniendo todos los acuerdos y resoluciones de cada ley". It was finally agreed in the $111^{\text {th }}$ session on $5^{\text {th }}$ February 1783, in accordance with the proposal by Porlier, that the secretary Penaranda should write up the laws of the future New Code according to the agreements adopted, and in which "vaya concluyendo cada título, lo trahiga para su reconocimiento y examen". From this moment, according to the $171^{\text {st }}$ Board session on $12^{\text {th }}$ January 1784, the Board methodically undertook a second revision of the laws to be compiled, parallel to the initial first examination or revision in order to

“dar la última mano a las leyes formadas con arreglo a los acuerdos resultantes de estas actas, para dexarlas, en quanto a sus sentencias y palabras, y a la coordinación que han de guardar en su colocación" 24.

This second revision of the Titles, successively from I to XIII, including Book I by Ansotegui, was in fact necessary due to the accumulation of individual votes, unanimous or majority agreements, and debates which had created distinct layers within the minutes that were recorded. Other reasons were the referred to postponement of the examination of some laws, which required background evidence and the transfer of charters from the Secretariats of the Council of the Indies, with the consequent delay for the rest of the laws in the same Title, and the complexity of placing, in the same act, laws that differed in their Title of origin and also differed in their ordinal position within the same Title. In spite of this, the rhythm of work by the Board of the New Code was at its fastest pace and most efficient when it was divided into a Particular and Plenary Board by the

\footnotetext{
${ }^{24}$ Acta de la Junta 108. a del Nuevo Código de Indias, de 13-I-1783 (AGI, Indiferente General, leg. 1.653, ff. 185 v-187 v). Acta de la Junta 111. a del Nuevo Código, de 5-II-1783 (AGI, Indiferente General, leg. 1.653, f. 189 r y v). Acta de la Junta 171. ${ }^{\text {a }}$, de 12-I-1784 (AGI, Indiferente General, leg. 1.653, ff. 287 v-289 r). Y Muro Orejón, A., El Nuevo Código de las Leyes de Indias. Proyectos de recopilación legislativa posteriores a 1680, pp. 27-28; e Id., "Estudio general del Nuevo Código de las Leyes de Indias», vol. II, pp. 24-25.
} 
RO of $30^{\text {th }}$ March 1788 . The daily work by the Conde de Tepa and de Pizarro in the Particular Board was worthy of praise: they prepared, coordinated and arranged the new laws to be compiled, and qualified the old ones with the collaboration of the scribe Represa as interim secretary, which facilitated the weekly or fortnightly work of the Plenary Board. In only five months of meetings, the Particular Board held daily sessions between $14^{\text {th }}$ April and $13^{\text {th }}$ September 1788, Tepa and Pizarro - and Represa - were devoted to the absorbing task of examining, arranging and extending the laws that would comprise the 26 Titles of Book I. To do this, they had at hand the extract that Represa had made of the agreements reached about each law, extracted from the minutes of the previous single Board. These titles of Book I were submitted by the Particular Board to the Plenary Board (Huerta, Bustillo, Tepa, Piñeres, Pizarro), who revised and approved them law by law with mere editing modifications to the text in nineteen sessions between $16^{\text {th }}$ July 1788 and $13^{\text {th }}$ December 1789. Once their initial task was completed, the Particular Board concentrated on reviewing the clean copy of the laws, in order to detect any errors, discordant concepts or words. Once this revision was completed, they started to draw up an alphabetical index of the laws contained in Book I. Represa, for his part, was entrusted with making a catalogue of the epigraphs of the laws for these 26 Titles, citing the royal charter each one had proceeded, accompanied by certain indications that distinguished whether the law was new or already compiled in 1680. its number, and whether it had been either fundamentally or only slightly altered ${ }^{25}$.
Alberto de la Hera carried out a pioneering study on the internal composition of the Board of the New Code, with respect to its well-known minutes of the first 250 sessions held between $16^{\text {th }}$ June 1776 and $18^{\text {th }}$ May 1785. His work, limited to Book I and comprehending the Bourbon Indian ecclesiastical law, although it included a high number of new laws - up to 267 out of a total of 733, which is more than thirty-six per cent, according to the not always accurate calculations by Muro Orejón-, it essentially modified the titles and their order, but paid hardly any attention to what had been projected by the royal compiling commissioner, Juan Crisóstomo de Ansotegui, or to the centenary Compilation by Carlos II of 1680, embellished with the pertinent legislation enacted by Felipe V, Fernando VI, Carlos III and Carlos IV. One must agree with De la Hera in the verifiable fact that the Board was divided, generaIly when debating about matters of competence and especially regarding the constitution of the Plenary and Particular Board. There were three groups, excluding Agüero, who died very early on, without having the opportunity to present his personal criterion, and Pizarro and Piñeres, who joined the Board after Casafonda's death and Porlier's promotion to Secretariat of State and of the Office of Grace and Justice of the Indies, at a time for which the minutes have not been conserved. On the one hand, the Conde de Tepa represented the positions of the most noticeable 'regalismo'- inclined to sustaining the thesis of the Royal Indian Vicariate - of Juan Solórzano Pereira or Francisco Salgado de Somoza, and he also concurred with the doctrine of Antonio José Ál-

\footnotetext{
${ }^{25}$ Muro Orejón, A., El Nuevo Código de las Leyes de Indias. Proyectos de recopilación legislativa posteriores a 1680, pp. 28-32; e Id., «Estudio general del Nuevo Código de las Leyes de Indias», vol. II, pp. 25-26.
} 
varez de Abreu, Pedro de Hontalva Arce, Antonio Joaquín de Rivadeneyra or Pedro Rodríguez Campomanes, which prevailed at that time or which they hoped would prevail. In the opposition was Bustillo, who was clearly more pro-ecclesiastical and less inclined towards ultramontanism, which was in favour of allowing the Church hierarchy the freedom to act. In the middle were Casafonda and Porlier, dean and fiscal of the Council of the Indies respectively, whose 'regalismo' was evidently and notably moderate. In the deliberations and the votes, Bustillo almost always counted on support from Domínguez and Huerta, especially the latter's; but Dominguez was often absent, and the result of many votes depended on the attitude of Casafonda and Porlier. Their attitude went beyond supporting Bustillo or even favouring with more frequency the thesis by Tepa, and aimed to achieve an eclectic or intermediary solution, with Tepa's opponents being persuaded to agree, that is to say, Huerta, Domínguez and even Bustillo himself. The truth is that the frontal defence, typically by the Conde de Tepa, of the 'Patronato Regio, based on the vicarial theory and ultimately dependent on pontifical concessions, yielded on occasions to Casafonda and Porlier's considera- tion that the 'Patronato' was another of the 'regalías' of the Crown, based on royal authority and not on pontifical authority, making any concession by means of a Papal Bull, brief, rescript or any other apostolic letter by the Roman Pope unnecessary and irrelevant ${ }^{26}$.

In the examination of the most relevant interventions by Porlier within the Board, Emma Montanos Ferrín has drawn the conclusion that his 'regalismo', far from appearing surreptitiously moderate as a result of the tense game of deliberations and votes within the Board, to achieve, along with Casafonda, 'regalista' laws that were substantially more 'regalista' than even those desired by Tepa, was in fact a sincerely moderate 'regalismo', not at all aggressive towards the consecrated privileges, exemptions and prerogatives of the Church. The growing 'regalista' policy during Carlos III's reign, sponsored by Campomanes from the Prosecution Office of the Royal Council of Castile, and shared by Francisco Carrasco de la Torre, future I Marquis of the Crown, from the Royal Council of Finance or by Manuel de Roda y Arrieta in the Secretariat of State and of the Office of Grace and Justice, directly affected the reduction of ecclesiastical jurisdiction. This would

${ }^{26}$ Hera Pérez-Cuesta, A. de la, "La Junta para la corrección de las Leyes de Indias», en AHDE, 32 (1962), pp. 567-580; Muro Orejón, A., "Estudio general del Nuevo Código de las Leyes de Indias", vol. II, pp. 61-69. Por ejemplo, sobre el regalista canario Antonio José Álvarez de Abreu (Isla de La Palma, 1688-Madrid, 1756), protegido de Melchor de Macanaz y ministro consejero togado de Indias desde 1731, autor de la célebre Víctima Real Legal. Discurso único jurídico-histórico-político sobre que las Vacantes Mayores y Menores de las Iglesias de las Indias Occidentales pertenecen a la Corona de Castilla y León con pleno y absoluto dominio (Madrid, Imprenta de Antonio Marín, 1726; $2 .^{a}$ ed. póstuma corregida y aumentada por el autor, Madrid, Oficina de Andrés Ortega, 1769), cuyas tesis fueron recogidas por un RD de 20-IX-1737, inserto en una posterior RC de 5-X, y le supusieron el galardón de un título de Castilla, el Marquesado de la Regalía, para él y sus sucesores, otorgado por Felipe $V$, con las que defendía una concepción providencialista de la política propia del Barroco hispano, la grandeza de la Monarquía española, la potestad del príncipe en los negocios espirituales y eclesiásticos, amén de la afirmación de los títulos de descubrimiento, conquista, dominación y gobierno para las Indias, sin desechar aunque sin exaltar tampoco el valor de la donación pontificia, puede acudirse a Víctor Tau Anzoátegui, "La Víctima Real Legal de Álvarez de Abreu en el pensamiento indiano", en las Actas del V Coloquio de Historia Canario-Américana, coordinadas por Francisco Morales Padrón, 4 vols., Las Palmas, Cabildo Insular de Gran Canaria, 1985, vol. I, pp. 959-983; ahora también en su colectánea titulada El Jurista en el Nuevo Mundo. Pensamiento, doctrina, mentalidad, Berlín-Fráncfort del Meno, Max-Planck Institut für europäische Rechtsgeschichte, 2016, pp. 71-96. Además de Alberto de la Hera, "Álvarez de Abreu y la naturaleza jurídica de los diezmos en Indias», en las Actas y Estudios del III Congreso del Instituto Internacional de Historia del Derecho Indiano, Madrid, Instituto Nacional de Estudios Jurídicos, 1973, pp. 803-826; e Id., "La regalía de las rentas eclesiásticas vacantes en la doctrina del jurista canario don Antonio Álvarez de Abreu», en las Actas del II Coloquio de Historia Canario-Americana, coord. por F. Morales Padrón, 2 vols., Las Palmas, Cabildo Insular de Gran Canaria, 1979, vol. II, pp. 225-246. 
be a tendency which would continue in the future and would inaugurate a new period of growing secularisation. The doctrinal foundation of this reduction in jurisdictional matters did not reside in custom, which could not be effective against the Crown and its 'regalías' but it resided in its objective of whether to address spiritual things or material interests. With respect to the right to attest in favour of the clergy or pro anima, as well as the payment of maintenance, the restitution of dowry or the attribution of litis expensas, existing as a consequence of matrimonial cases of separation (divorce), or other similar cases, it was understood that there was absolutely no spiritualty for them to be heard on the basis of ecclesiastical jurisdiction. It was not a case of interference in the spiritual sphere by the royal power, but a recuperation of lost jurisdictional areas, as occurred with the 'regalía' of amortisation so that the mortmain properties could pass from ecclesiastical power of to that of laymen ${ }^{27}$.

The fact that Book I of the New Code of the Indies was not published nor generally enforced was seen as a complete failure of the Indian compiling work undertaken in the reign of Carlos III, continued during Carlos IV's reign, and resumed during Fernando VII's reign. Although the exact reasons that led to this failure are unknown, Antonio Muro Orejón in 1929 understood it was because the ministers-councillors of the Royal Council of the Indies were upset because the Board of the New Code had been given legislative authority through a RD of $7^{\text {th }}$ September 1780 , irrespective of the powers belonging to the Supreme Synod, which had prevented them from partici- pating in a work which they had wanted to leave their mark on. So, in their consultation of $26^{\text {th }}$ April 1794, it would be recorded that the Council of Indies, meeting in the Government Chamber, was opposed to the publication of Book I until it was revised by the Plenary Council. This was finally resolved by Carlos IV through another RD of $9^{\text {th }}$ July 1799, which said that once analysed by Antonio Porcel, the secretary of the Council and of the Chamber, Book I should be passed on to the council itself and should undergo the previously requested examination. The frictions and disagreements between entities -especially between a Royal Council and its off-shoot, the extraordinary Compilation Board-, can never be disregarded or underestimated, but other circumstances deriving from the content itself of the compiled work are also important factors. In 1949, Manuel Giménez Fernández pointed out that the failure of the Church reform of the Indies during the reign of Carlos III, which started in 1768 with the reforms of Religious Orders and the celebration of provincial Councils for the secular clergy instigated by the Tomo Regio or ' $R C^{\prime}$ ' of $21^{\text {st }}$ August 1769, led to an attempt to establish a renewed spiritual government with Book I of the New Code between 1776 and 1790/1792; however, with the Floridablanca's fall from power in 1792, it soon had to be abandoned. Not even the Holy Seat's approval of the 'regalista' canons of the IV Mexican Provincial Council of 1771 had been possible and was explicitly advised against by successive plenipotentiary ministers of the Catholic Monarchy, José Nicolás de Azara on 28 ${ }^{\text {th }}$ March 1792, and Pedro Gómez

\footnotetext{
27 Sánchez Bella, Ismael, «Reducción de la jurisdicción eclesiástica en América bajo Carlos III. (Testamentos y Matrimonio)», en la Revista Chilena de Historia del Derecho, Santiago de Chile, 12 (1986), pp. 223-262, luego reproducido, con variantes, en su Iglesia y Estado en la Amé- rica española, Pamplona, Eunsa, 1990, pp. 177-212; y Montanos Ferrín, E., "Antonio Porlier como regalista indiano", en Ius Canonicum, Pamplona, XXXI, 62 (julio-diciembre, 1991), pp. 575-619.
} 
Labrador on $21^{\text {st }}$ October $1801^{28}$.

For his part, in 1962, Alberto de la Hera accepted both of the earlier theses by Muro Orejón and Giménez Fernández. Firstly, he understood the New Code to be a principle instrument in the reformist policy of the Church of the New World, sustained by Carlos III and his ministers, and abandoned when this policy was understood to be ineffective. However, de la Hera notes that Carlos IV did not decide to disregard Book I, but simply that it should not be revised. He acknowledges the corporative jealousies of the Royal Council of the Indies, and their urge to intervene in the compiling work, as well as the link between the failure of the ecclesiastical reform and that of the New Code, but not that the New Code itself failed, despite this attempted reform, since the compiling task was in fact resumed. Secondly, for De la Hera, there is no doubt that Carlos IV's ministers did not dare to publish Book I, which had a highly 'regalista' tone, nor the canons approved by the IV Mexican Council, and attributes this radical 'regalismo' to Tepa rather than Casafonda and Porlier. Since the minutes of the Plenary and Particular Boards, created through a $\mathrm{RO}$ of $30^{\text {th }}$ March 1788, have not appeared, De la Hera hypothesises that as Porlier and Casafonda had left the Board before its division, Book I "obra de la Particular, que revisa y enmienda todo lo hecho hasta allí, was in Tepa's hands. Since his only colleague, Pizarro, had just joined the Board, he was inexperienced and unfamiliar with what had been previously deliberated, or how and why it had been decided to compile again what had already been compiled up to then. In the daily meetings of the exiguous Particular Board, the Conde de Tepa would have asserted his personal criteria without any difficulty, emphasising the 'regalismo' of the laws in Book I, making it difficult for the Plenary Board, comprising Huerta, Bustillo, Tepa, Pizarro and Piñeres, but in which «dominaba Bustillo, pudiese borrar la obra de Tepa sólo a base de sesiones semanales o quincenales» ${ }^{29}$.

Nevertheless, in my opinion, De la Hera makes excessive suppositions and hypotheses when he attributes 'regalismo' exclusively to the Conde de Tepa. A 'regalismo' he qualifies as radical and observable in specific laws -although the most significant, distinctive and decisive- of Book I, in the New Code of the Indies of 1792. This minister-councillor of the Indies and member of the Board was not the only 'regalista', since such an attitude and activity is also recognised in Casafonda and Porlier; besides, Bustillo and even more so Dominguez and Huerta also maintained positions reputably and generically 'regalista'. It is true that they did not lead in its defence and advocacy, but just became the silent majority, formed without any difficulty for the general tone of the laws of Book I with few or no disputes and total facility in many of the ordinary sessions of the single Board of the New Code. In addition, simply reading the minutes from these 250 sessions convinces us that it was not so much what the Conde de Tepa from the Particular Board had devised and altered, but in general just improvements to the text

\footnotetext{
${ }^{28}$ Muro Orejón, A., El Nuevo Código de las Leyes de Indias. Proyectos de recopilación legislativa posteriores a 1680, passim; Id., "Somero estudio sobre los proyectos del Nuevo Código de las Leyes de Indias», en el Boletín del Instituto de Investigaciones Históricas, Buenos Aires, 11 (1930), pp. 19-28; Id., "Leyes del Nuevo Código vigentes en América», pp. 448-471; e Id., "Estudio general del Nuevo Código de las Leyes de Indias", pp. 51-52; y Giménez Fernández, M., "Las Regalías Mayestáticas en el Derecho Canónico Indiano. (Apuntes para desarrollar una lección del Programa de Instituciones Canónicas en el Derecho Indiano)", en el Anuario de Estudios Americanos (AEA), Sevilla, 6 (1949), pp. 799-811.

${ }^{29}$ Hera, A. de la, "La Junta para la corrección de las Leyes de Indias», pp. 572-575.
} 
which had been adopted when Casafonda and Porlier were still present. Of course, these corrections were often not naïve, neutral or insipid but completely the opposite, deeply 'regalista'. On occasions, Tepa did convince the Plenary Board of the New Code to totally and radically change what had been agreed some time before by the single Board. However, because there are no the minutes from the Plenary and Particular Board, we do not know with what arguments and by what means, but for this very reason, biased and unlawful intentions or achievements cannot be attributed to him, and it cannot be assured that he was its only driving force. An example of this was the proverbial case of the new law in first place of Title II. Del Patronato Real, which raised the theory of the Royal Indian Vicariate to the condition of 'regalía' of the Crown: $\mathrm{NCl}, 1,2,1$. La delegación de la Silla Apostólica se tenga por una de las más preeminentes regalías. (L. N. RC by Carlos III, of $14^{\text {th }}$ July 1765. Carlos IV in this Code).

One thesis, that of the Catholic Kings of Spain being Vicars and delegates of the Apostolic Seat for the spiritual government of the Indies, had been explicitly rejected by Casafonda and Porlier and the other members of the Board in the meetings of the single Board, with the exception of its driving force the Conde de Tepa. In this case, Tepa did manage to make a radical change, but we do not know, as there are no sources available, the how and why this minister-councillor of the Indies and member of the Board managed to impose an absolute turnaround. This is particularly surprising since Huerta and Bustillo were still active, their vote was as equally valid as the 'regalista' Conde's and they had been present and given their opinions in the sessions of the single Board as well as in the subsequent sessions of the Plenary Board. Is it that the Conde de Tepa simply made use of the votes by Pizarro and Piñeres to assert his personal and obstinate 'regalista' criteria in the face of the presumed opposition of Huerta and Bustillo? The latter were two of the most senior ministers in a society, that of the Ancien régime, which was so respectful to their status in general and especially in the administrative world. Were their powers of persuasion so slight or null that they did not always obtain support, not even from one of the two members, Pizarro or Piñeres? Too many unanswered questions and unsolved mysteries to be able to sustain with such conviction, as shown by De la Hera, that the axis on which the notorious 'regalismo'- in my opinion marked 'regalismo' rather than radical- of Book I of the New Code of the Indies turned, was exclusively due to the Conde de Tepa in the period from the RO of $30^{\text {th }}$ March 1788 until the consultation by the Board of $2^{\text {nd }}$ November 1790.

I also disagree with the conclusion manifested by De la Hera, based on the previous observations by Muro Orejón and by Giménez Fernández, that Book I was not published after the Carlos IV's RD of approval, dispatched in Aranjuez on $25^{\text {th }}$ March 1972, because of Caballero's fear of its marked 'regalismo'. Firstly, José Antonio Caballero was not secretary of State and of the Office of Grace and Justice until March 1792 and the person that did not dare to publish it was none other than Porlier, Antonio Porlier y Sopranis, I Marqués de Bajamar from $12^{\text {th }}$ March 1791, former fiscal and future governor of the Council of the Indies, and member of the board of the New Code between 1776 and 1787, as we already know. It is also known that the person who directed the general policy of the Monarchy in March 1792 was the first secretary of the Office of State, Pedro Pablo Abarca de Bolea, $X$ Conde de Aranda, who replaced José Moñino y Redondo, I Conde of Floridablanca as interim on $27^{\text {th }}$ February 1972, and was also dean of the revived Council of State. He would be succeeded by Manuel Godoy Álvarez de Faria, I Marqués de la Alcudia on the 15th November 1792 until $28^{\text {th }}$ 


\section{THE BOARD OF THE NEW CODE OF THE INDIES (1776-1820): OBSERVATIONS AND \\ CLARIFICATIONS FOR A REVISED INTERPRETATION \\ Dr. José María Vallejo Garcia-Hevia}

March $1798^{30}$

Apart from this, Casafonda and Porlier's control over the final decisions - at least the majority of them -, adopted by the Board of the New Code should be understood as almost always joint prevalence of opinion, which managed to win over the opposing and dissenting criterion of some or all of their remaining colleagues, especially Tepa and Bustillo's. In the face of the less 'regalista' or more pro-ecclesiastical positions of Bustillo - who Huerta usually supported-, and the fiercer 'pro-regalista' positions of the Conde de Tepa, the moderate 'regalismo' of the president and of the member-fiscal prevailed on most occasions, winning over Dominguez when he attended the sessions or alternatively Tepa or Bustillo and Huerta. It is true that Casafonda had been prosecutor of New Spain, in the Council of the Indies between 1766 and 1773 and immediate predecessor to Porlier, who was prosecutor between 1773 and 1787, that is to say for almost the whole period of the New Compilation Board. Both prosecutors, Casafonda and Porlier, maintained the same coordinated defence strategy, the preservation and in some cases, improvement or moderate increase in the 'regalías' of the Crown. But all without the stridencies or maximalisms that could annoy, question or complicate the general policy of institutional -and even historically doctrinal- relations between the Catholic Church and the Spanish Crown.

In Book I of the New Code of the Indies of
1792, the compilation of the Bourbon legislation for the ecclesiastical government of America and its Title II, in which the Patronato Real constitutes its cornerstone institution, the new law $(\mathrm{NCl}$, $1,2,1)$, introduced at the request of the Conde de Tepa, seems like a strange member within a legal body that in matters of 'Real Patronato' maintained the general lines of Title IV of the Compilation of the Indies of 1680. The new coding Board is aware of the existence of course of two 'regalista' tendencies. On the one hand, the traditional tendency that Bustillo would represent, which required the prior pontifical concessions like the Papal Bulls of Pope Alexander VI of 1493. On the other hand, the innovative tendency specific to the $18^{\text {th }}$ century which Tepa would catalyse, understanding the 'regalías' of the Crown as natural rights of the temporal sovereign without the need of briefs or Papal Bulls ${ }^{31}$.

In the History of the Indian 'Regio Patronato', it has been agreed that there are three distinct stages each coinciding with one of the centuries of the Modern Age: The Real Patronato itself which would coincide with the $16^{\text {th }}$ century; that of the Royal Vicariate, identified with the $17^{\text {th }}$ century; and that of the Regalismo, already characteristic of the $18^{\text {th }}$ century. From the start, the law of the 'Patronato Real' was gradually understood to be

${ }^{30}$ Gómez Rivero, Ricardo, Los orígenes del Ministerio de Justicia (1714-1812), Madrid, Ministerio de Justicia, 1988, anexo I. Los miembros del Ministerio de Justicia (1714-1812): datos biográficos, núms. 6 y 7, pp. 92 y 93; y Badorrey Martín, Beatriz, Los orígenes del Ministerio de Asuntos Exteriores (1714-1808), Madrid, Ministerio de Asuntos Exteriores, 1999, parte III. Ministros y oficiales de la Secretaría (1714-1808). Informes biográficos, núms. 9, 10 y 11, pp. 467-469.

31 Hera, A. de la, "Las leyes eclesiásticas de Indias en el siglo xviii”, en Estudios Americanos, Sevilla, XVI, 86-87 (noviembre-diciembre, 1958), pp. 239-252; Id., El Regalismo borbónico en su proyección indiana, Madrid, Rialp, 1963, pp. 109-159; e Id., "La legislación del siglo xviii sobre el Patronato Indiano", en $A H D E, 40$ (1970), pp. 287-311, con su tesis de que el regalismo hispano no quiso la ruptura, y sí sólo la confrontación, entre la Iglesia y la Monarquía, y de ahí su confusa búsqueda de fundamentación vicarial, esto es, en concesiones pontificias, de las regalías de la Corona, desarrollada en las pp. 297-302. 
more and more favourable to the Crown. In practice, the only true ecclesiastical intervention in America, which the Holy Seat never left in the hands of the Monarchs, was the appointment of Bishops and Archbishops, and the creation of dioceses and overseas metropolitan provinces. In fact, the Catholic Kings of Spain became delegates of the Holy Seat for the ecclesiastical government of the Indies, that is to say, Vicars of the High Pontiff.

The Indian 'Real Patronato' was based on the political thesis of pontifical theocracy. imposed on Christian Europe since 476 AD, after the fall of the Western Roman Empire; a doctrine according to which God governed the world through his Vicariate, the Roman Pope. As Vicar of God on Earth, the Pope was empowered according to pontifical theocracy to divest Christian Princes of their sovereignty if they acted for evil and not for good; in the same token, a Prince considered as more suitable was conceded the right to conquer the lands of infidels with the inherent duty of Christianising them in order to obtain their eternal salvation. One of the most transcendent Papal Bulls issued in the Indies was the Universalis Ecclesiae by Julius II, signed on $28^{\text {th }}$ July 1508 , according to which it corresponded to the Castilian Kings and their successors to erect, found and provide the churches of the New World, which could not be carried out by third persons without royal consent. The monarchs also had the 'right of presentation' regarding the provision of all ecclesiastical posts and benefits. Although the content of this Papal Bull of 1508 was very limited, it did lead to the extension of royal authority over the Indian Church through its broad interpretation especially since the reign of Felipe II and his 'patronal' RC of $1^{\text {st }}$ June 1574, in which the Holy Seat was forced to tolerate: a) the founding and endowment of churches, presentation of candidates for the posts and benefits of the church, the receipt of tithes, the creation of dioceses in America and fixing their limits b) also the concession of cédulas de ruego $y$ encargo ${ }^{32}$ for governing the bishoprics in 'sede vacante', the right to intervene in the appointments of the Superiors of the Religious Orders, or the frequent royal settlement of the disputes between the Bishops resident in the Indies and the Regular Orders; c) the celebration of the Diocesan Synods and provincial Councils, the reduction of ecclesiastical privileges, the conflicts of jurisdiction between royal and ecclesiastical tribunals especially regarding cases of mixed jurisdiction (perjury, usury, sacrilege, non-heretic blasphemy), the moderation and the limitation of the sentences of ex-communion as well as those of prohibition and cessation a divinis, the establishment of the Holy Office of the Inquisition in the New World since 1569, the receipt of espolios ${ }^{33}$ and vacant posts, vigilance so that preachers would not denigrate civil authorities from the pulpit, the regulation of the right to asylum in spite of being one of the ecclesiastical immunities, the prohibition of personal ad limina visits by Prelates and other regular and secular clergy and providing Rome with accounts about the state of the dioceses, interference in the banishment of clerics and religious people because of a licentious or scandalous lifestyle, and control over journeys by Prelates and other regular and secular clergy; d) without forgetting the royal pass or regium exequatur, the prohibition of rea-

\footnotetext{
${ }^{32}$ Cédulas de ruego y encargo: Official documents which requires and orders a mandate to be implemented.

${ }^{33}$ Espolio means goods that were acquired with ecclesiastic funds, so when the clergy who owned them died ab intestate, they would become the property of the church.
} 
ding and publishing the Papal Bull In Coena Domi$\mathrm{ni}$, the 'recursos de fuerza' ${ }^{34}$ before civil tribunals against the sentences from ecclesiastical judges, or the attempt to appoint the Nuncio for the Indies and to create a Patriarchy of the Indies ${ }^{35}$.

The Royal Indian Vicariate was not, however, a term or an appointment that would appear in the Papal Bull Universalis Ecclesiae of 1508. Hence, in the second half of the $16^{\text {th }}$ and during the $17^{\text {th }}$ century a search would be made for the primary source of this term in the Papal Bull Inter caetera $\mathrm{II}$ and that of Eximiae devotionis of $4^{\text {th }}$ and $3^{\text {rd }}$ May 1493 respectively, through which Alexander VI had given the Catholic King and Queen, Isabel and Fer- nando, a general mandate for the evangelisation of the Indies as a condition and consequence of the donation of the lands discovered and those to be discovered there, and the concession of their royal sovereignty over them. It was supposed that by virtue of such a command of evangelisation, entrusted by the Apostolic Seat to the crown, they had been implicitly or explicitly delegated by the Pope to exercise all the powers, belonging to the Supreme Pontiff, required for preaching to and converting the native American infidels. In this sense, the Castilian Catholic King and Queen as pontifical delegates and vicars governed the Church of the Indies by the grace of the Alexandrian Papal Bulls

34 Recurso de fuerza is a procedure related to the patronato, regarding the clergy's authority to appeal to the ordinary courts against resolutions by the ecclesiastic courts.

35 De la frondosa bibliografía sobre la materia patronal indiana, cabe acudir a Gómez Zamora, Matías, Regio Patronato Español e Indiano, Madrid, Imprenta del Asilo de Huérfanos del Sagrado Corazón de Jesús, 1897; Ayala y Delgado, Francisco Javier de, «Iglesia y Estado en las Leyes de Indias», en Estudios Americanos, Sevilla, I, 3 (1949), pp. 417-460; Gutiérrez de Arce, Manuel, «Regio Patronato Indiano. (Ensayo de valoración histórico-canónica)», en AEA, Sevilla, 11 (1954), pp. 107-168; Hera, A. de la, «El Regio Patronato de Granada y las Canarias», en AHDE, Madrid, $27-28$ (1957-1958), pp. 1-12; Egaña, Antonio de, "El Regio Vicariato Hispano-Indiano. Su funcionamiento en el siglo xvi», en Estudios de Deusto, Bilbao, VI, 11 (1958), pp. 147-204; e Id., La teoría del Regio Vicariato español en Indias, Roma, Pontificia Universidad Gregoriana, 1958; Leturia, Pedro, «El origen histórico del Patronato de Indias. Un problema de actualidad hispanoamericana», "Un párrafo más sobre el origen del Patronato de Indias», "Novum Spagnole nomen, o nuevas aclaraciones sobre la Bula inicial del Patronato de Indias», "El Regio Vicariato de Indias y los comienzos de la Congregación de Propaganda Fide» y "La Bula del Patronato de las Indias españolas que falta en el Archivo Vaticano", en sus Relaciones entre la Santa Sede e Hispanoamérica, 3 tomos, t. I. Época del Real Patronato, 1493-1800, t. II. Época de Bolívar, 1800-1835 y t. III. Apéndices, documentos, índices, Caracas, Sociedad Bolivariana de Venezuela, $1959, \mathrm{t}$. I, pp. 1-31, 33-48, 49-58, 101-152 y 233-258; Hera, A. de la, "El Regio Patronato español de Indias en las Bulas de 1493», en AHDE, 29 (1959), pp. 317-349; Peraza de Ayala, José, "El Real Patronato de Canarias», en AHDE, 30 (1960), pp. 13-174; Gómez Hoyos, Rafael, La Iglesia de América en las Leyes de Indias, Madrid, Consejo Superior de Investigaciones Científicas (CSIC), 1961 ; Castañeda Delgado, Paulino, La teocracia pontifical y la conquista de América, Vitoria, Eset, 1968; Hera, A. de la, "El Patronato Indiano en la Historiografía eclesiástica», en Hispania Sacra, Madrid, 32 (1980), pp. 229-264; Hermann, Christian, L'Église d'Espagne sous le Patronage Royal (1476-1834). Essai d'ecclésiologie politique, Madrid, Casa de Velázquez, 1988; Cantelar Rodríguez, Francisco, "Patronato y Vicariato Regio español en Indias», en las Actas de la XX Semana Luso-Española de Derecho Canónico. Derecho Canónico y Pastoral en los descubrimientos luso-españoles y perspectivas actuales, Salamanca, Universidad, 1989, pp. 57-102; Hera, A. de la, "El Regio Vicariato de Indias», en su Iglesia y Corona en la América española, Madrid, Mapfre, 1992, pp. 255-273; e Id., "El Patronato y el Vicariato Regio en Indias», en Pedro Borges (dir.), Historia de la Iglesia en Hispanoamérica y Filipinas. (Siglos xv-xix), 2 vols., Madrid, Biblioteca de Autores Cristianos (BAC), 1992, vol. I, pp. 63-79; Arvizu y Galarraga, Fernando de, "Una nueva interpretación de la teoría del Regio Vicariato Indiano", en Ius Canonicum, Pamplona, XXXVI, 71 (1996), pp. 63-99; Barrio Gozalo, Maximiliano, El Real Patronato y los Obispos españoles del Antiguo Régimen (1556-1834), Madrid, CEPyC, 2004; Maqueda Abreu, Consuelo, "Evolución del Patronato Regio. Vicariato indiano y conflictos de competencias", en Feliciano Barrios (coord.), El Gobierno de un Mundo. Virreinatos y Audiencias en la América Hispánica, Cuenca, Universidad de Castilla-La Mancha, 2004, pp. 795-829; Cruz Barney, Óscar, «Relación Iglesia-Estado en México. El Regio Patronato Indiano y el

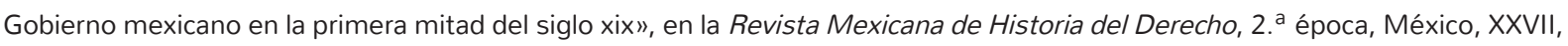
1 (enero-junio, 2013), pp. 117-150; y Galán Lorda, Mercedes, "ElRegio Patronato Indiano», en José Antonio Escudero (dir.), La Iglesia en la Historia de España, Madrid, Fundación Rafael del Pino y Marcial Pons, 2014, pp. 607-623. 
with full jurisdiction which they could not be deprived of, since they had fulfilled their obligation of evangelising. Already in the $18^{\text {th }}$ century, the vicarial law of the Crown changed from being a mere pontifical concession, to become a regalía, a natural right that belonged to them. That is to say, the King and Queen were not, with respect to their patronal powers, the Vicars of the Pope, but directly the Vicars of God. For the 'regalistas' God had shared out power in the world, granting the Pope only the dogmatic and sacramental aspect -and even this under the protective power and control of the temporal sovereigns- and the King and Queen were granted all the temporal power, in both the civil and ecclesiastical sphere. The regalia, as a royal right of the Crown, which corresponded to the King as such, ended up being identified with the ecclesiastical right of the temporal sovereign. Just like regalismo, it was the triumphant doctrine in the century of Enlightenment, which considered that the sovereign Princes had the power to govern over ecclesiastical issues, not in virtue of the pontifical Bulls or apostolic privileges, granted by the Roman Pontiff, but founded in their very condition as temporal sovereigns. The extension for the Crown, or the interference for the Church, of the royal or temporal power in the legal-economic sphere was considered in fact a necessary defence of the rights of the King (his regalías), in contrast to real or imaginary invasions of ecclesiastical authority and power ${ }^{36}$.
The 'regalista' conception and its varying practices of galicanismo in France, febronianismo in Germany, josefismo in Austria, jurisdiccionalismo in Italy or pombalismo in Portugal, reached its maximum expression precisely with the so-called freedoms of the Gallican Church. This was specified in the Declaration of the general Assembly of the French Clergy of 1681-1682, accepted by Louis XIV, through an edict of $23^{\text {rd }}$ March 1682, which affirmed in four articles that: the Pope did not have authority in secular concerns, and was unable to depose Princes or absolve subjects from their sworn loyalty; the general Council was superior to the Roman Pontiff; the pontifical power was limited by the laws accepted by the whole church and by the laws and customs admitted in the Kingdom and Church of France; pontifical dogmatic declarations were only infallible if they had the approval of the Church. Apart from this, the principle 'regalista' institutions, which were so active in the $18^{\text {th }}$ century, stipulated that the royal rights necessary for the defence of the Church by the royal power were: placet or regium exequatur, apellatio in abu$s u$, specified in the ecclesiastical 'recurso de fuerza', and ius patronatum. They all lasted even after the Decree of unification of jurisdictions of 6th December 1868, which abolished the privilegium fori of the clergy, such as: the 'pase regio' for pontifical provisions, the Penal Code of 1870 in its article 144 still sanctioned the ecclesiasts that did not respect it; or the 'recurso de fuerza', present in the

\footnotetext{
${ }^{36}$ Solórzano Pereira, Juan, Política Indiana [1647], edición de Francisco Tomás y Valiente y Ana María Barrero, 3 tomos, Madrid, Fundación José Antonio de Castro, 1996, t. II, lib. En que se trata de las cosas eclesiásticas, y Patronato Real de las Indias, cap. II. Del Patrona- to Real en todo lo eclesiástico de las Indias, de las Bulas Apostólicas y razones en que se fundan, pp. 1218-1231. Y Cantelar Rodríguez, F., «El Patronato Regio de Indias en Solórzano Pereira», en J. Solórzano Pereira, De Indiarum lure. (Liber III: De retentione Indiarum), edición y estudios preliminares de Luciano Pereña, Carlos Baciero, Jesús María García Añoveros, Antonio García y García, y F. Cantelar Rodríguez, Madrid, CSIC, 1994, pp. 193-205. Además de Sánchez Bella, I., Iglesia y Estado en la América española, Pamplona, Eunsa, 1990, ya citada, parte I. Actitud de la Santa Sede ante el Patronato Indiano y parte II. El Regalismo indiano en el siglo xviii, pp. 55-106 y 107-315; García Añoveros, Jesús María, La Monarquía y la Iglesia en América, Madrid, Asociación Franci López de Gómara, 1990, pp. 70-75, 116-119 y 126-133; y Barrientos Grandón, Javier, El Gobierno de las Indias, Madrid, Fundación Rafael del Pino y Marcial Pons, 2004, pp. 71-97.
} 
Constitution of 1812 (arts. 261, num. 8 and 266), in the provisional Organic Law of Judicial Power of 1870 (arts. 390 and 399, and the following), or in the Civil Trial Law of 1881 (arts. 112 and 125 and fol.), although reduced to the modality of 'fuerza en conocer', the 'fuerzas en el modo de proceder $y$ en no otorgar' were abolished. In this respect, Isabel II, in a RO of $15^{\text {th }}$ March 1856 to the Governor of Puerto Rico, had expressed her agreement with a previous RC from Carlos III of $14^{\text {th }}$ July 1765 that the Kings of Spain, as Vicars and delegates of the Apostolic Seat, were competent to intervene in anything concerning this.

\begin{abstract}
“al gobierno espiritual de las Indias, con tanta amplitud que, no sólo les está concedido por la Santa Sede sus veces en lo económico de las dependencias y cosas eclesiásticas, sino también en lo jurisdiccional y contencioso, reservándose tan sólo aquella potestad de orden, de que no son capaces los seculares; y debiendo observarse sus determinaciones, por los eclesiásticos, como leyes y rescriptos apostólicos" 37 .
\end{abstract}

However, in practice, Spanish Bourbon 'regalismo' of the 18th century did not manage to modify the Crown's scope of competence over the Church of the Indies. It was rather a doctrinal movement, a new way of understanding and expressing royal authority over ecclesiastical matters. This was because the Crown did not have an official doctrine about 'regalismo', although it admitted some of the principles defended by 'regalista' authors, like: the direct divine origin of royal power (descendancy theory) without having to undergo any mediation by the people (ascendancy theory), to whom they did not justify any of their acts; support for moral rigour as opposed to probalism, condemning the doctrines of tyrannicide and resistance to the temporal sovereign; the national sense of the Church and its defence from the economic abuses of the Roman Curia and Dataria; or absolute obedience and submission to the monarch, understood as Father and Master of his people. The Crown did not present its 'regalías' as majestic rights inherent to the royal sovereign in any provision or regulation. To the contrary, it stressed that these inviolable, imprescriptible and intangible 'regalías' were derived from the Papal Bulls and Briefs or at most immemorial customs. The best proof of all this resides in the Concordat signed by Benedict XIV and Fernando VI on $11^{\text {th }}$ January 1753, which was extended to the peninsular Kingdoms of the Catholic Monarch and the Real Patronato of the Crown in its overseas territories. Far from proceeding unilaterally, Fernando VI waited to obtain rights through the pontifical concession, in the concordat of $1753^{38}$. In the following reign of his half-brother Carlos III, the purest orthodoxy,

${ }^{37}$ García Añoveros, J. M. a , La Monarquía y la Iglesia en América, cap. IV, epígr. VII. El gobierno espiritual de las Indias bajo los Borbones, núm. 1. Las intervenciones reales en el gobierno espiritual. c) El Regio Vicariato, pp. 126-133; la cita, en la p. 127 in medias. En general, López Ortiz, José, El regalismo indiano en el "Govierno Eclesiástico-Pacífico» de Don Fr. Gaspar de Villarroel, O. S. A., Obispo de Santiago de Chile, Madrid, 1947; Rodríguez Casado, Vicente, "Notas sobre las relaciones de la Iglesia y el Estado en Indias en el reinado de Carlos III», en la Revista de Indias, Madrid, 43-44 (1951), pp. 89-109; y Hera, A. de la, "Los precedentes del regalismo borbónico según Menéndez Pelayo", en Estudios Americanos, Sevilla, 14 (1957), pp. 33-39; e Id., "Notas para el estudio del regalismo español en el siglo xviii», en $A E A$, Sevilla, 31 (1974), pp. 409-444.

38 Véanse, al respecto, Alonso, Santiago, El pensamiento regalista de Francisco Salgado de Somoza (1595-1665). Contribución a la Historia del Regalismo español, Salamanca, Universidad, 1973; Domínguez Ortiz, Antonio, "Regalismo y relaciones Iglesia-Estado en el siglo xvii» y Egido, Teófanes, "El regalismo y las relaciones Iglesia-Estado en el siglo xviii», en Ricardo García-Villoslada (dir.), Historia de la Iglesia en España, vol. IV. La Iglesia en la España de los siglos xvii y xviii, dirigido por Antonio Mestre Sanchís, Madrid, BAC, 1979, pp. 73-121 y 123-249; Díaz de Cerio, Francisco, "Jansenismo histórico y Regalismo borbónico español a 
respect and faithfulness to the catholic faith were combined with the most scrupulous and energetic defence of the 'regalías', as is clearly expressed in chapters I, II and III, in the very frontispiece of the Instrucción reservada for the Supreme Board of State, created by a RD of $8^{\text {th }}$ July 1787 :

“I. Se encarga el cuidado de la religión católica y de las buenas costumbres. Como la primera de mis obligaciones, y de todos los sucesores en mi Corona, sea la de proteger la religión católica en todos los dominios de esta vasta Monarquía, me ha parecido empezar por este importante punto, para manifestaros mis deseos vehementes de que la Junta, en todas sus deliberaciones, tenga por principal objeto la honra y la gloria de Dios, la conservación y propagación de nuestra santa fe, y la enmienda y mejora de las costumbres.

II. Obediencia a la Santa Sede en las materias espirituales. La protección de nuestra santa religión pide necesariamente la correspondencia filial de la España y sus soberanos con la Santa Sede, y así la Junta ha de contribuir con todas sus fuerzas a sostener, afirmar y perpetuar esta correspondencia, de manera que en las materias espirituales, por ningún caso, ni accidente, dejen de obedecerse y venerarse las resoluciones tomadas en forma canónica por el Sumo Pontífice, como Vicario que es de Jesucristo y Primado de la Iglesia universal.

III. Defensa del Patronato y regalías de la Corona con prudencia y decoro. Pero, como además de los decretos pontificios, canónica- mente expedidos para las materias espirituales, pueden mezclarse o expedirse otros que tengan relación con los decretos de patronatos y regalías, y con los asuntos de disciplina externa, en que, por las mismas decisiones eclesiásticas y por las leyes reales y costumbre inmemorial, me corresponden facultades que no se pueden, ni deben, abandonar, sin faltar a las más rigorosas obligaciones de conciencia y justicia, conviene que la Junta, cuando pudiere mezclarse alguna ofensa de aquellos derechos y regalías, me consulte los medios prudentes y vigorosos de sostenerlas, combinando el respeto debido a la Santa Sede con la defensa de la preeminencia y autoridad real" 39 .

It was the examination of the fundamental Title VI. Del Patronato Real de las Indias from the 1680 Compilation, in the version projected by Ansotegui in 1780, which would end up being Title II. Del Patronato Real in the New Code of 1792, that led to the debate about the 'regalía' of the Apostolic Vicariate for America, delegated by the Roman Pontiffs in the Kings of Spain. The first thorough examination took place between the $30^{\text {th }}$ Board session of $10^{\text {th }}$ December 1781 and the $47^{\text {th }}$ session of $4^{\text {th }}$ March 1782; its revision or second examination lasted from the $191^{\text {st }}$ session of $12^{\text {th }}$ May to the $211^{\text {th }}$ session of $18^{\text {th }}$ August 1784; its correction was initiated during the phase of Particular Board in the session of $17^{\text {th }}$ May 1788, while its revision by the same Particular Board took place in the meetings of $17^{\text {th }}, 18^{\text {th }}$ and $20^{\text {th }}$ October

finales del siglo xviii», en Hispania Sacra, Madrid, 33 (1981), pp. 75-116; Hera, A. de la, "El Regalismo indiano", en P. Borges (dir.), Historia de la Iglesia en Hispanoamérica y Filipinas. (Siglos xv-xix), vol. I, pp. 81-97; Salido López, Mercedes, El derecho de Patronato en el pensamiento jurídico-regalista de Mayans, Granada, Comares, 2009; y Hera, A. de la, "El Regalismo borbónico», en J. A. Escudero (dir.), La Iglesia en la Historia de España, pp. 645-659.

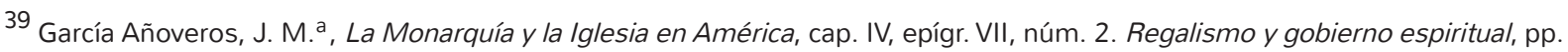
133-136; y la Instrucción reservada de la Junta Suprema de Estado, en Escudero, J. A., Los orígenes del Consejo de Ministros en España. La Junta Suprema de Estado, 2 tomos, Madrid, Editora Nacional, 1979 (2. a ed., Madrid, Editorial Complutense, 2001), t. II, ap. doc. núm. I, pp. 13-157; la cita, en las pp. 15-16. 
1788, but individual and certain laws would continue to dominate some later sessions like those of $13^{\text {th }}$ or $30^{\text {th }}$ January 1789. In the Plenary Board, deliberations were initiated in the meeting of $27^{\text {th }}$ November and continued into that of Wednesday $3^{\text {rd }}$ December 1788, complemented by other later sessions on $24^{\text {th }}$ and $28^{\text {th }}$ January 1789 . In the $203^{\text {rd }}$ Board meeting of $5^{\text {th }}$ July 1784 , the matter under discussion was the monarch or temporal sovereign's 'regalía' as delegate of the Apostolic Vicariate regarding spiritual and ecclesiastical matters. After reading the Papal Bull, Inter Caetera, by Pope Alexander VI of $3^{\text {rd }}$ May 1493, the unanimous agreement was that this law must not be adopted but the members of the Board differed about its rationale. The opinion of the majority, represented by Huerta, Bustillo and Porlier, was in favour of omitting any mention of the royal delegate of the Apostolic Vicariate in the New Code. This was because the Spanish monarch exercised it effectively and its legal expression would lead to nothing but doubts, questions, disputes, since they understood that the Inter Caetera could not be interpreted clearly enough nor was it decisive enough for the foundation of such a prerogative. The dissenting vote by the Conde de Tepa, however, argued that it was an excellent 'regalía' which should appear explicitly in the New Code, in the form of this law, of a new law or of a clause integrated in another law, and to do so he submitted his individual vote which appeared in the minutes of the $43^{\text {rd }}$ Board of $18^{\text {th }}$ February 1782. At the $204^{\text {th }}$ Board session of $12^{\text {th }}$ July 1784 , the prosecutor Porlier specified that in order to establish a compiled law that would explicitly declare the King as Apostolic Vicar, this must be acknowled- ged beforehand in a pontifical Bull containing this concession, as he believed the simple opinion of some authors who understood it in this way was not enough ${ }^{40}$.

Almost four years later, in May 1788, according to records, the particular Board corrected and amended Title VI. by Ansotegui in detail. Therefore, in its session of $17^{\text {th }}$ May 1788, the first 46 laws drawn up by Ansotegui were examined. In general, the agreements made about them were confirmed in the unitary Board of the New Code. It is important to highlight the amendment to a previously recorded new law, which had not been contemplated in the sessions for which the secretary Luis Peñaranda had drawn up the minutes, and which had been placed as number one of Title VI, although it would be based on a RC by Carlos III of $14^{\text {th }}$ July 1765: L. N.; NCl, I, 2, 1. La delegación de la Silla Apostólica se tenga por una de las más preeminentes regalías. It was clear that in the long term the Conde de Tepa had triumphed over his Board colleagues, Huerta, Bustillo and Porlier, who manifested such an opposing opinion, as seen in the $203^{\text {rd }}$ session of $5^{\text {th }}$ July 1784 . Taking advantage of his subsequent presidency of the Particular Board and especially the disappearance of Casafonda, who had passed away, and of Porlier which had been promoted to minister, Tepa managed to impose his 'regalista' criteria in opposition to his three colleagues. At that time, they would have to omit or supress even mentioning the Apostolic Vicariate of the Crown over the Indies, since the King exercised it effectively, which was what counted - according to Bustillo, Porlier and Huerta-, it could only lead to arousing undesirable doubts, questions and disputes ${ }^{41}$.

\footnotetext{
${ }^{40}$ Acta de la Junta 203. ${ }^{a}$ del Nuevo Código, de 5-VII-1784 (AGI, Indiferente General, leg. 1.653, ff. 331 v-332 v). Acta de la Junta 204. ${ }^{a}$ del Nuevo Código, de 12-VII-1784 (AGI, Indiferente General, leg. 1.653, f. 333 r y v). Y acta de la Junta $43 .{ }^{a}$, de 18-II-1782 (AGI, Indiferente General, leg. 1.653, ff. 90 v-93 r).
}

${ }^{41}$ Borrador del acta de la Junta Particular, de 17-V-1788 (AGI, Indiferente General, leg. 1.652, s. f.). 
The regalía of the government decrees that the King ordered to be dispatched to the elected diocesan and metropolitan Prelates of the Indies corresponds to Book I Title IV. De los Arzobispos y Obispos y Visitadores Eclesiásticos in the New Code of 1792 (Title VII, in the Compilation of 1680; and in the proposed version by Ansotegui in 1780). The reason for these cédulas de ruego $y$ encargo was the excessive duration of the episcopal 'sedes vacantes' in the Indies, and a need for the Crown to ensure the complete deference of the Prelates. Consequently, serious precautions were taken in the selection of the candidates, and in addition, Archbishops and Bishops had to take an oath in defence of their 'regalías'. The procedure to cover the episcopal 'sedes vacantes' in America through the legitimate exercise of the royal right of presentation was slow and notably exacerbated by the distances and the great slowness in communications. Many years would pass from the time a Bishop or Archbishop died until the news of their death seat reached the political capital of the Viceroyalty, and from there the Court in Spain, where the mechanism for selecting the candidate and his presentation before the Pope was put in motion. This would be followed by: the pontifical confirmation, the issuance of the Papal Bulls with the appointment and canonical institution, a communication to the interested party, the new Prelate's journey to his diocesan or metropolitan seat in the New World, his consecration and taking possession of his post. According to canonical Law in the time that elapsed, the 'sede vacante' should be governed by the Cabildo of the cathedral, who acted through the 'vicar capitular', who was therefore chosen by him. In order to reduce the vacancy period as much as possible, the Crown stipulated that as soon as the new Prelate was chosen and while the long procedures for his appointment were being carried out, the elected person had to travel immediately to his future seat and start to govern and be invested as 'Vicar capitular'. In order that the ecclesiastical Cabildo would in fact choose him for this interim post, the Crown provided the elected Bishop or Archbishop presented to the High Pontiff, with cédulas de ruego y encargo, in which the temporal sovereign urged and requested the Cabildo to make sure that the already presented Prelate would be elected 'Vicar capitular'.

It is easy to imagine that the Cabildo could not deny a royal petition which meant that the person appointed for the provisional government of the dioceses or metropolitan province, who would enjoy its profits and benefits, would necessarily have to become Bishop or Archbishop of the dioceses or metropolitan province. It is also easy to imagine that the Holy Seat never accepted this practice, which was an inadmissible procedure, where a candidate, who still had not been accepted and confirmed by the Roman Pontiff, was to govern de facto as Bishop or Archbishop. This procedure was said to be based on a former custom, where a candidate, in order to avoid possible canonical censors, was appointed to govern through the ecclesiastical Cabildo, who had the right to do this. In other words, the candidate did not take canonical possession of the post but was granted it by means of a petition de ruego y encargo. When the pontifical Bulls arrived with his appointment, the designated person received the episcopal consecration, if he was not a Bishop, and took solemn canonical possession of his Mitre. However, Pius IX finally put an end to this practice, prohibiting it 
under the sentence of ex-communion, although at a somewhat later date $-28^{\text {th }}$ August $1853^{42}$.

The six ministers-councillors of the Board of the New Code of the Indies, Casafonda, Domínguez, Huerta, Tepa, Bustillo and Porlier, attended their $43^{\text {rd }}$ session on $18^{\text {th }}$ February 1782 . They deliberated at length about whether it was in fact better to leave the above-mentioned 'regalía', as a modest note, or make it an explicit law in Title VI. of Book I of the New Code. This regalia, stemming from the 'Real Patronato', appears in the executive royal charters that the temporal sovereign ordered the government to issue to the elected Bishops or Archbishops when a Cathedral of the Indies had a 'Sede Vacante', so that in the time it took for the Roman Pontiff's confirmation and fiat to arrive, and before his pontifical Bulls of consecration could be fulfilled, they could govern their respective dioceses and archdioceses or metropolitan provinces. The Board's agreement was not unanimous, but it was approved by a majority, since the Conde de Tepa disagreed with a dissident vote which was noted in the minutes. Most of the Board, that is Casafonda, Domínguez, Huerta, Bustillo and Porlier, agreed on the need to draw up a law that would come before the $32^{\text {nd }}$ law (I, 6, 32, of the Book I Project by Ansotegui of 1780), based on the concise wording of the submission note of 'encargo y ruego' that the elected Prelates should govern the dioceses for which they were presented although not yet consecrated, and that the cathedral Cabildos should allow them to do so:
"A la pluralidad se acordó que, sin entrar, ni tocar, en modo alguno, sobre el derecho en que se funda la práctica constante y facultad del Rey en librar las Cédulas de Gobierno a los nuevos electos, se forme una lei con las propias palabras de la dicha nota, en la que, por decisión, se concluya rogando y encargando, a los prelados electos, tomen el Govierno de las Iglesias a que están presentados, y a los Cabildos que lo dexen gobernar, usando la lei, en esta última parte, las mismas voces de que usa el formulario de estas Cédulas, que observan las Secretarías, la qual se coloque en el dicho Titulo 6. ${ }^{\circ}$ del Patronato Real, en el lugar más oportuno y precediendo a la otra en que se establece que, hallándose dichos Prelados electos en sus Iglesias, asistan y voten en las oposiciones a prebendas de las mismas" 43

In this $43^{\text {rd }}$ session of $18^{\text {th }}$ February 1782 , the Conde de Tepa made a particular and individual vote related - as noted - to the government charters that the Kings had delivered to the elected Archbishops and Bishops so that they could rule their dioceses and American metropolitan provinces before even receiving the confirmation and the fiat of the High Pontifices. His discrepancy resided in that he believed that an explicit law should not be expressed in the same formulation used in such ecclesiastical government charters that were circulated and administered bureaucratically by the New Hispanic and Peruvian Secretariats of the Royal Council of the Indies. Tepa

\footnotetext{
42 Hera, A. de la, "El Gobierno espiritual de los dominios ultramarinos», en F. Barrios (coord.), El Gobierno de un Mundo. Virreinatos y Audiencias en la América Hispánica, pp. 865-904. También García Añoveros, J. M. ${ }^{\text {a }}$ La Monarquía y la Iglesia en América, pp. 91-92 y 115-116; Bruno, Cayetano, El Derecho Público de la Iglesia en Indias. Estudio histórico-jurídico, Salamanca, CSIC, 1967, pp. 249-253; y Prien, Hans-Jürgen, La Historia del Cristianismo en América Latina, Salamanca, Sígueme, 1985, pp. 124 y ss.

${ }^{43}$ Acta de la Junta 43. a del Nuevo Código de Indias, de 18-II-1782 (AGI, Indiferente General, leg. 1.653, ff. 90 v-93 r; la cita, en los ff. 90 v-91 r).
} 
wanted it to be stated that, in virtue of the 'Real Patronato', which the spiritual and temporal government of the New World was united to, "nos pertenece induvitablemente, como a legados natos de la Silla Apostólica, el derecho y facultad de despachar y expedir, como se han despachado y expedido hasta ahora, nuestras Cédulas Reales a las Iglesias Cathedrales de nuestras Indias en sede vacante, y de los Arzobispos y Obispos de ellas, presentados por Nos para que, antes de estar confirmados y consagrados, puedan governar sus respectivos Arzobispados y Obispados". This also implied that the exclusion of clauses allowing the Cabildos in 'sede vacante' to empower Archbishops and Bishops to govern the dioceses. Tepa sustained, to be exact, that the law to be compiled could not rogar y encargar the ecclesiastical Cabildos in 'Sede Vacante' of the American dioceses to empower their elected but not consecrated Prelates to govern, but that they should simply be allowed to govern. This was because both expressions involved completely different concepts about the scope of the Indian 'Regio Patronato' which the temporal and spiritual government of the New World were linked to. According to Tepa, the King was the Apostolic Vicar, or the Apostolic Sear, in the Indies. Hence, in his opinion, the idea of the Cabildos of the 'Sede Vacante' empowering the elected Prelates to govern was contrary to the royal 'regalía', because the Castilian monarchs had been granted an apostolic ministry and had the authority corresponding to their legacy since the Catholic Kings. Tepa argued that the legal principle of dependence of the 'podatario'44 with respect to the 'poderdante'45 in matters of ecclesiastical jurisdiction had not been verified in the elected $\mathrm{Bi}$ shops, who had been transmitted jurisdiction not through the power of the Cathedral Cabildos in 'Sede Vacante' but in virtue of the pontifical faculty that the temporal sovereign exercised, such as one of his regalías ${ }^{46}$.

However, in the following Board session, the $44^{\text {th }}$ of $20^{\text {th }}$ November 1782 , the president, Casafonda, and the prosecutor, Porlier, with the support of the rest of the members, Domínguez, Huerta and Bustillo, formulated a joint rebuttal. In 1680 , the compilers of the laws of the Indies had abstained from introducing any law related to the government decrees addressing the Cathedrals in 'Sede Vacante'. Likewise, neither had the Indian Royal Council wanted to establish the principle of this 'regalía' of the Crown, and in the first final apostille of RI, I 6. 6. Del Patronazgo Real de las Indias, simply expressed that in virtue of his 'Regio Patronato', the King had the authority for such charters to be dispatched, and so it was executed. If the Board of the New Code now wanted to raise this apostille to the category of new codified law, Casafonda and Porlier announced that the Board should diverge as little as possible from the wording, intellect and the spirit of such an apostille and from the formulation used by the synodal Secretariats. In fact, if in the cited apostille the Monarch was said to have the privilege of issuing the abovementioned government charters, and this was done with the expression empower to govern, it was clear that this custom had already existed some time before, founded on possessory acts or examples. In opposition to the legal recognition of the theory of the Royal Vicariate, both Casafonda

\footnotetext{
44 Podatario is the person who represents someone in a legal act.

45 Poderante is the person who empowers or authorises another to represent them in a legal act.

${ }^{46}$ Acta de la Junta 43. ${ }^{a}$ del Nuevo Código, de 18-II-1782 (AGI, Indiferente General, leg. 1.653 , ff. 90 v-93 r; la cita, en el f. 91 v)
} 
and Porlier understood, in contrast to the Conde de Tepa, that nothing was assured in applying to the King to dispatch the diocesan government charters in question to the cathedral cabildos, since they were not founded on a presumed sovereign capacity of natural Legacy or on the Apostolic Vicariate of the Holy Seat. What is more, such a concept of a 'regalía' of the Crown, based on the royal condition of Apostolic Vicariate of the Holy Seat would diminish it rather than enhance it, since it would seem inferior if the Monarch were to dispatch decrees as a simple order or commission from the Pope and not in his own name, by right of 'regalía' and universal patron acquired by immemorable custom and possession.

In other words, the 1680 compilers, did not base the regalía in question on sound advice, but simply presented it in an apostille, and abstained from introducing a law about it. Now, the post 1780 pseudo-codifiers had settled on raising this apostille to a formal law, diverging as little as possible from the wording, intellect and spirit of said apostille, as well as from the formulation of the government charters used in the Secretariats of the Council of Indies, in which the expression empower to govern had always appeared. In Casafonda and Porlier's view, in the canons set out by the councils, episcopal jurisdiction in the case of 'vacante' should fall on the Cabildo, since it was purely a spiritual right, which the royal legal authority could not deprive them of. Therefore, the Cabildos did not delegate their jurisdiction in the elected Prelates, but assigned and transmitted it, renouncing it by request of the temporal sovereign. Casafonda and Porlier, in contrast to Tepa, did not believe that the King was Apostolic Vicar or natural Legate of the Pope either, since this would undermine or depreciate the 'regalía' rather than enhance it. This would mean that government charters would be dispatched by a mere agent, representative or commissioner of the Roman
Pontiff, rather than in the monarch's own name, as universal patron, acquired by an immemorial custom and possession. To sum up, for the majority of the Board, changing the standards of the charter's formulation by the Secretariats would leave them open to litigation. It was one thing 'rogar $y$ encargar' the Cabildos in 'Sede Vacante' to give up their right, and another to deprive them of it without their acquiescence, and it was to be expected that all the ecclesiastical Cabildos of the Indies in such a circumstance would stand up against such an innovation. Thus, by the joint insistence of Casafonda and Porlier, a law was finally formed and approved (that of $\mathrm{NCl}, \mathrm{I}, 2,11$. Los Prelados presentados pasen luego a sus Iglesias y tomen el gobierno de ellas, como se expresa), completely in line with the first apostille of RI, I, 6, and formulated in the same tone as the Secretariats of the Council of the Indies, with the following proposal:

"Lei. Que los Prelados electos para los Obispados de Indias, luego que reciban sus despachos, se encaminen a sus Iglesias y las gobiernen, y los Cabildos sede vacante los dexen gobernar, dándoles poder para que ínterin llegan las Bulas, practiquen todo lo que los mismos Cabildos podían exercer en sede vacante".

Estando Nos, en virtud de Nuestro Real Patronato, en posesión de que se despache nuestra Cédula Real, dirigida a las Iglesias Cathedrales sede vacante, para que entre tanto que llegan las Bulas de Su Santidad y los presentados a las Prelacías son consagrados, les den poder para gobernar los Arzobispados y Obispados de las Indias, lo que así se executa; por tanto, rogamos y encargamos de los Prelados así electos que, luego que reciban sus despachos, se encaminen a sus respectivas Iglesias $y$ presenten en los Cabildos de ellas las cartas 
que para ellos se les entregaren, encargándoles les den poder para que gobier- nen dichos Obispados ínterin llegan las enunciadas Bulas; y que conviniendo en ello los Cabildos (como esperamos que convendrán), se ocupen y entiendan los dichos Prelados en su Gobierno. $Y$ así mismo rogamos y encargamos a los dichos Cabildos sede vacante reciban a los tales Prelados y los dexen administrar las cosas del Obispado, dándoles poder para que, en el expresado medio tiempo, hasta llegar las Bulas, practiquen todo lo que los mismos Cabildos podían exercer en sede vacante"47.

\section{THE NEW LAW CODE OF THE INDIES: A RENEWED INTERPRETA- TION ABOUT ITS CONTENTS AND PREPARATION}

In 1776, Carlos III decided to have a New Code drawn up because of the need to make additions and enlighten the very outdated 1680 Compilation with the royal resolutions and subsequent edicts that had been agreed and were in line with the constitution of the current government of the Kingdoms of the Indies. The goal of the compiling technique would continue to be that of ordering the many disperse regulations that formed the royal Law in force in a determined territory. Undoubtedly, it was not a private compilation, but from the moment it was commissioned by the sovereign it became official. The systematic criterion followed in the Indian Compilation of 1680, as with that in the Castilian Compilation of 1567, meant that the New Code would not be of a chronological nature, but it would follow an order of grouping the laws in force according to the subject; it would not be a complete and literal reproduction of the compiled texts, but like its Castilian-Indian predecessors it would adhere to rewriting and altering precepts for the sake of briefness. The addition to and enlightenment of the 1680 Compilation of the Indies in 1776 dismisses on principle that Carlos III wanted the new legal work to be a Code that imitated the enlightened European models, although in the RD of $9^{\text {th }}$ May 1776 it was explicitly mentioned as the attainment of a new Code of the Indian laws. Consequently, this projected new code of the Indian laws was yet another Compilation of historic Castilian and Hispanic Law which over time would also foreseeably require completion because its contents would become outdated. It would be a Compilation of the $17^{\text {th }}$ Century, updated again, but not in tune with the current and new legal-political, economic and social times of the end of the $18^{\text {th }}$ Century, but with an identical method, aim, arrangement and order: that of the traditional medieval ius commune. The aim was to select in an ordered way, needless to say, following the established and intellectual order of the Ancien Régime, and to update, under the current royal absolutism still in force, the laws of the public and private Castilian-Indian Law: everything that was understood as adding to and enlightening or reforming and improving outdated and useless laws, under the reign of Carlos III in Spain.

Legal thinking about the Enlightenment could not convince the circle of the Spanish Monarchy of the need to enact Codes in the same way as other European absolutist Monarchs, like those of Prussia or Austria. Neither was their influence strong

${ }^{47}$ Acta de la Junta 44. ${ }^{a}$ del Nuevo Código, de 20-II-1782 (AGI, Indiferente General, leg. 1.653, ff. 93 r-97 r; la cita, en los ff. 96 v-97 r). Y el tenor de la referida remisión o apostilla 1. ${ }^{a}$ de RI, I, 6. Del Patronazgo Real de las Indias: "Su Magestad, en virtud del Patronazgo, está en posesión de que se despache su Cédula Real, dirigida a las Iglesias Catedrales Sede vacantes, para que entre tanto que llegan las Bulas de Su Santidad, y los presentados a las Prelacías son consagrados, les den poder para gobernar los Arzobispados y Obispados de las Indias, y así se executa". 
enough for an advanced codifying Project under royal auspices to triumph, although it were only in name, like the Ferdinand Code of Fernando VI in 1752; or so that it would appear as a true penal Code and enlightened penal procedure, like the plan of the future criminal Code presented to the Conde de Floridablanca by Manuel de Lardizábal and the Board of ministers-councillors of Castile, entrusted with drawing up this criminal Code in 1787. Both Codes, the one proposed to Fernando $\mathrm{VI}$ and the one under debate for Carlos III, were only ambiguous, limited and disperse attempts by a minority who wanted a legislative reform in line with the latest European model of enlightened Codes, within a Monarchy strongly tied to the regulations of the Ancien Régime. Simple attempts, mere proposals that were not even frustrated, since their execution had not been initiated and less so projected; in any case, only suggested, commented, desired in private by certain enlightened ministers, attentive to the development of the latest doctrinal, philosophical and legal currents that prevailed in Europe. There was no legislative coding policy carried out in Spain, from the heights of sovereign power, to the contrary, from this height of political power, both the King and the Royal and Supreme Councils, like those of Castile and that of the Indies, which embodied his manifestation, promoted, sponsored and imposed continually, determinedly and uninterruptedly the most conservative and stagnant compilation policy ${ }^{48}$.

It is known that unlike the Compilation, the Code would be characterized by its methods and precepts, that is to say for its rational rather than empirical or systematic method; and for its preceptive, regulatory and non-doctrinal nature. However, the Compilation had been defined as being not only pre-methodical, but explicitly anti-methodical. It did not require a method because current law was not based on it, and the idea of establishing one was not even envisaged. Besides, method within a legislative body could supplant doctrine which had traditionally defined and developed the more general principles of the constituted legal and political order. In this sense, while the compiled law was subordinate to doctrine and history, it could not avoid being very casuistry, only slightly systematic and with almost no generality in its provisions. In contrast, the coded law would prevail over doctrine and history which would permit its regulatory systematicity and generality. However, when the idea of the Code was conceived in the discourse of the $18^{\text {th }}$ century legal Enlightenment, its affirmation came at the same time as the theoretical denial of political, and even economic and social order that existed then, that of the Ancien régime with its deeply medieval roots. This implied a constitutive contradiction, since if the Code presupposed a legislative conception of the legal order, which the presence of a constituent legislative power necessarily arose from, such a power could neither exist nor be represented by that of the kings of the absolute Monarchies; nor could the coded laws subsist or even appear within a legal order which was formally obstructed by doctrine and history, and materially inherent in secular privileges, corporative, stately and jurisdictional rights. In the end, the Codes appeared when Law became autonomous, when the secular and civil legal order was sepa-

\footnotetext{
${ }^{48}$ Así lo vio, agudamente, y lo consignó incluso en una exposición de conjunto, en la que procuraba dejar constancia de sus reflexiones y novedades investigadoras, Francisco Tomás y Valiente, Manual de Historia del Derecho Español, $4 .^{a}$ ed., Madrid, Tecnos, reimpresión de 1992 (1. ${ }^{a}$ ed., 1979; $4 .^{a}$ ed., 1983), caps. XXII. La crisis del Derecho al final del Antiguo Régimen y XXVI. La Codificación, fenómeno europeo. Etapas de la codificación en España, pp. 383-398 y 465-492, en general; ya en particular, pp. 395-397 y $476-478$.
} 
rated from religion, from the ordo iuris ecclesiae: one of the main, if not the first, of the constituted powers, pledged throughout the Ancien Régime in the Middle and Modern Ages with the conservation of an established hierarchically dominant social, political and economic universe ${ }^{49}$.

The New Code of the Indies was not therefore a Code (except in a non-technical-legal sense, and it was generical, whose historical antecedent would be, for example, the old Roman Justinian code, or like others with similar names Código de Huesca or el Código de las Siete Partidas). Neither was it an innovation, since it consisted of a simple, although laborious and debated update of the Compilation of 1680. In 1792, Carlos IV, another king to be dethroned in the future, like Louis XVI in France, recently dethroned after a few months into his reign, resolved to give all the jurisdiction and authority necessary to Book I of the renovated project of an enlightened 'Carolino' Compilation. The aim was not just to improve the knowledge and application of royal legislation additionally enacted for the Indies for almost a century, but to also leave implicit proof of its explicit, traditional and extant observance. This was particularly the case with respect to the firm validity of the historical political-social and economic structures of the Ancien Régime on both sides of the Atlantic Ocean and throughout all the extensive domains of the Hispanic Monarchy. Thus. there was nothing unusual that, in times and places where the Law continued to be heteronomous, given its interdependent relations with Religion, the 'Carolino'
Bourbon and Indian compiling movement would respect the multi-secular and basal structural order of the compilation. In this way, the New Code would be presented again in its Book I, the only one finally approved, with everything concerning ecclesiastical law and jurisdiction and with the same rubric for its title I: De la Santa Fe Católica. This is how it had been since the $13^{\text {th }}$ Century, in the late Middle Ages with the 'Partidas' (the first of seven, as in the Espéculo) and the Fuero Real (the first of four books); and in the Modern Age with the so-called Ordenamiento de Montalvo of 1484 (the first of eight), the New Compilation of 1567 (book I, of nine), and of course the Compilation of the Indies of 1680, also divided into nine books, which would figure in the Newest Compilation of 1805, the first of its twelve books. Obviously, for almost fifteen years nothing could be found of a rational and systematic method nor preceptive regulations in the minutes of the sessions of the officially baptized Board of the New Code of the Indies. However, what could be found was a great empirical method of doctrinal and historical precepts, casuistry and particular regulations. All of them were symptoms of the corporative, feudal and ecclesiastical, jurisdictional, binding privileges and easements that were sought to be continuaIly accumulated and legally perpetuated within the hierarchies that continued to shape the society of the Ancien Régime.

\footnotetext{
${ }^{49}$ Clavero, Bartolomé, "La disputa del método en las postrimerías de una sociedad, 1789-1808», en AHDE, Madrid, 48 (1978), pp. 309-334; e Id., "La idea de Código en la llustración jurídica», en Historia, Instituciones, Documentos (HID), Sevilla, 6 (1979), pp. 49-88. Amén de Peset Reig, Mariano, "Una propuesta de Código Romano-Hispano, inspirada en Ludovico Antonio Muratori», en los Estudios Jurídicos en Homenaje al Profesor Santa Cruz Teijeiro, 2 vols., Valencia, Universidad, 1974, vol. II, pp. 217260; e Id., "Derecho Romano y Derecho Real en las Universidades del siglo xviii», en AHDE, 45 (1975), pp. 273-339; y Tomás y Valiente, Francisco, "La Codificación, de utopia a técnica vulgarizada», en sus Códigos y Constituciones (1808-1978), Madrid, Alianza, 1989, pp. 111-124. Además de Escudero, J. A., "Sobre la génesis de la Nueva Recopilación», en AHDE, 73 (2003), pp. 11-33; y Galván Rodríguez, Eduardo, Consideraciones sobre el proceso recopilador castellano, Las Palmas de Gran Canaria, Universidad, 2003, pp. 8-95.
} 
The New Code of the Indies from 1792 was not New neither was it even an enlightened Code. This is the thesis presented in these pages, but not however that of Ezequiel Abásolo, who conceives Spanish Law of the $18^{\text {th }}$ century as a modern regulatory expression. In his aim to provide some alternative proposals about the reasons and the circumstances that led to the secular culture of the ius commune being substituted by the codification, this author criticises the confusion of current legal Historiography regarding the coding process and its results. He identifies the type of rationalist and bourgeois Code proposed in the $18^{\text {th }}$ and $19^{\text {th }}$ centuries, as the only regulatory instrument of universal application and inevitable character compatible with Modernity. His thesis is that the compiling proposals of Carlos III and Carlos IV's collaborators tended towards a type of regulatory production that not only differs from the legal rationalism that prevailed in the west, but it also diverges from what characterised the Castilian legal entities from the end of the $15^{\text {th }}$ century. Based on the fact that the New Code was only a Compilation, as it was called on many occasions by the members of the Board of the New Code themselves, Abásolo did not see it as an anachronicistic compilation or that it lacked innovations. Taking advantage of the percentages provided thirty years earlier by Muro Orejón, he notes that the New Code was a second-grade compilation integrated in its single Book I by 32 per cent of the old laws, another 32 per cent of variations of old laws, and finally 36 per cent of post 1680 new laws. He also highlights that the Board of the New Code always maintained the criterion of conserving the greatest number of old laws possible, on considering it improper to introduce laws without reason. In this sense, if old laws were to be abolished, there was always an attempt to base this on solid reasons: their presumed uselessness, their superfluous or redundant condition, contradiction with laws subsequent to the compiled laws, or the consideration that they dealt with matters foreign to those of the royal legislative authority.

Remembering that it was the Conde de Tepa who defended the inherent legitimacy of the incorporation of the original laws in the New Code, Abásolo also highlights that the audacious changes in the Indian legislation could have been done with or without the precepts pertinent to the Royal Charters subsequent to 1680. Another distinctive note was that there was a tendency towards the 'castellanización' of the new or original laws included in the New Code, without forgetting the variation in the numeration of the laws and titles with respect to the Compilation of 1680. Abásolo understood that the underlying legal theory in drawing up the new Code of 1792 was defined on the basis of six criteria: 1.) Royal legislation constituted the absolute authority of the monarch, indifferent to the criticism of his subjects. The right to legislate came within the first royal 'regalías', in which the passing of the laws was understood to belong to the King, as is their publication, printing and reprinting, even without having to give a reason for establishing them. Hence the Board would have done without the preambles introduced by Ansotegui to his proposed laws and would have omitted all the unnecessary explanations included in them 2.) The regulation contained in the laws had to have a general scope and not deal with mere providences of good government or the remedy of abuses introduced. 3.) The laws that dealt with the same matters had to be governed by the same principles, maintaining due uniformity through cross-references, without contradictions or incompatibility. 4.) The multiplicity of laws about a samee subject had to be avoided through combination or elimination, legal conciseness being one of the main concerns of the Board of the New Code. 5.) The drawing up of the laws had to be dynamic and laconic in order to avoid 
confusion and contradiction. The legal style had to be clear and without ambiguities. 6.) The conflict between laws and customs was solved by giving prevalence to the provisions of the former laws and not the latter ${ }^{50}$.

Abásolo concludes his analysis of the legal conception of $18^{\text {th }}$ century Spain, in view of the New Code of 1792, affirming that legal absolutism advanced in the Hispanic Enlightenment, anticipating the $19^{\text {th }}$ century coding process. Although it was generally sustained that the Enlightenment had not managed to renew the Codes in Spain, and simply added some minor changes to the laws in force in order to minimally modernise them, but not without ambiguities and inconsistencies, within the Board of the New Code the enlightened legislative policy had been integrated with "elementos mucho más cercanos a la modernidad racionalista de lo que los iushistoriadores veníamos admitiendo hasta el momento" ${ }^{51}$.

However, Abásolo does not provide an in-depth justification for such a conclusion. Looking further into the legislative rhetoric of the $18^{\text {th }}$ century, Francisco Pacheco Caballero provides a contrasting conclusion about the delay in Hispanic political ideas. While in other Western European latitudes criticism of the absolute Monarch as a form of government started during the $18^{\text {th }}$ century, Spain continued to move deeper into 'regalismo' and the notion of sovereignty and the issue of the absolute authority of the kings. This does not mean however it was totally resistant to the doctrines coming from abroad, which in any case were considered mere political curiosities. Legislative discourse was not oblivious to this legal-political phenomenon, consequently alongside the issues characteristic of the Enlightenment, there was a constant concern for the defence of sovereignty and the 'regalías' of the Monarch, although the argument at times draws on the clichés of the Enlightenment. One pragmatic argument, the enlightened one, which put a great emphasis on the notions (argument of the positive consequences) of usefulness, advantage, benefit, perfection, and progress; contrasting them (argument of the negative consequences) when necessary with the opposite notions: prejudice, deterioration, abuse, negligence, and drawbac-

\footnotetext{
${ }^{50}$ Abásolo, E., "La Junta Revisora del Nuevo Código de las Leyes de Indias y las concepciones jurídicas dieciochescas", en su "Animado Yo de los mismos deseos de mi Augusto Padre». Estudios y documentos sobre la fijación del Derecho de la Monarquía Española durante la época de Carlos IV, en E. Martiré (coord.), La América de Carlos IV. Cuadernos de Investigaciones y Documentos, vol. V, Buenos Aires, Instituto de Investigaciones de Historia del Derecho, 2009, ya citado, pp. 15-32. Y Muro Orejón, A., «Estudio general del Nuevo Código de las Leyes de Indias», pp. 61-63.
}

51 Abásolo, E., "La Junta Revisora del Nuevo Código de las Leyes de Indias y las concepciones jurídicas dieciochescas», pp. 25-32; la cita literal, en la p. 32. Según este mismo autor, las Recopilaciones borbónicas (el Nuevo Código de Indias de 1792, y la Novísima Recopilación de España de 1805), no carecían de orden sistemático, aunque no fuese el racional ilustrado y normativo, por no existir una sola y exclusiva idea de sistema jurídico. Y debían ser incluidas en la Modernidad jurídica, moderada y no radical o revolucionaria, por soslayar las referencias a la doctrina, tan propia del ius commune, y basarse en el absolutismo regio. En sus leyes irrumpen, por lo demás, conceptos como los de Estado y Nación, que aludían ya a estructuras políticas impersonales, frente a las personales regias y polisinodales de la Monarquía de los siglos xvi y xvii. Asegurada, en fin, la primacía de la ley sobre la costumbre, se garantizaba, en suma, la primacía legal de la Corona. La modernidad moderada de las Recopilaciones setecentistas se inclinaba más por una conciliadora reforma jurídica gradual que por la ruptura drástica del orden normativo preexistente, en pro de un progreso político absolutista, y no liberal, mediante sus mecanismos de omisión de leyes y de reasignación de su destino, siempre que, como quería Cayetano Filangieri, la diversidad de las leyes particulares e históricas no resultase incompatible con la racionalidad de las leyes universales (Abásolo, E., «El reformismo normativo borbónico: ¿Vía alternativa a la modernidad jurídica?», en su "Animado Yo de los mismos deseos de mi Augusto Padre». Estudios y documentos sobre la fijación del Derecho de la Monarquía Española durante la época de Carlos IV, pp. 75-86). 
ks. All this through the cliché of experience and the dialectics between the goal and the means so characteristic of a utilitarian discourse which the enlightened discourse was, in which the validity criterion of success became fundamentally important, the problem of the relations between the means proposed and the achievement of the goal. The conception of power that revealed the use of different forms of argument and different clichés included the humanitarian ideal of the Enlightenment. When Carlos III, or Carlos IV, proclaimed himself Sovereign and father and protector of my peoples, two different conceptions of political power were synthesised in the same formula: the traditional one, according to which, the conservation and the increase of power corresponded to the sovereign; and the new and typically enlightened one, through which it corresponded to the sovereign to procure the happiness, culture and well-being of the people. This was expressed legislatively through arguments like those of general interest; protection, happiness, prosperity comfort of the subjects; their public quietude and tranquillity. A paternalist discourse, in short, the enlightened one, with the omnipresent figure of the King (Royal person, Royal authority, Royal will, Royal permission, Royal approval, Royal licence, Royal piety, Royal clemency), as the protector of the Catholic faith, ecclesiastical discipline and canons ${ }^{52}$.

All of this explains why there is no trace in the more than 250 minutes conserved of the Board of the New Code about the debates that occurred between the members related to fundamental issues and intrinsically related to the legal matters to be compiled, particularly the Fundamental Laws of the Monarchy (Andrés Marcos
Burriel, Pedro Rodríguez Campomanes, Gaspar Melchor de Jovellanos, Francisco Martínez Marina). In other words, regarding the great issue at that time, that of legal Enlightenment: that of specifying which regulations would contribute to a balance of powers, and some powers that would be reciprocally limited in favour of the rights and freedoms of citizens, who, on the other hand, were subjects of an absolute Monarch. This was raised publicly, at least by Montesquieu, who since 1748 in his De I'Esprit des Lois, expounded on the British Constitution or the Constitution of England, admired for its historical, common law and unwritten quality, but especially because it was neither republican nor democratic. What had attracted both Montesquieu and William Blackstone with their Commentaries on the Laws of England (1765), or Jean Louis De Lolme from Geneva and his Constitution de I'Angleterre (1771), was its government regime based on the balance or equilibrium or powers, which would guarantee the freedom of the people, because they believed its division of powers and its mild or moderate defence of freedom, constituted a more efficient prevention against despotism. In spite of the pactism theories, characteristic of medieval political and legal thought, when talking of Fundamental Laws (of the inalienability and indivisibility of the 'patrimonio regio' with respect to the laws and jurisdiction of the Cortes, of the approval of new extraordinary taxes or services by the Kingdom in the Cortes, of the law of succession to the Crown, of the defence of the Christian religion and the consubstantial Catholicism of the Monarchy) being able to moderate the absolute nature of the royal authority, it was understood that they originated from history, as its tacit traditional ma-

\footnotetext{
52 Pacheco Caballero, F. L., "Retórica, tópica y legislación en el siglo xviii», pp. 479-503; y Álvarez de Miranda, P., Palabras e ideas: el léxico de la llustración temprana en España (1680-1760), pp. 43-67 y siguientes.
} 
nifestation rather than from explicit or legal pacts between the King and the Kingdom.

Not even the slightest reference was made to these legal-political questions in any of the records. They did not warrant any mention in the agreements, the individual votes and the majority votes of its ministers, not even in the debates of the Board of the New Code of the Indies. This was the case, despite the fact that in 1785 , as appendix to the second volume of Historia política de los establecimientos ultramarinos de las naciones europeas (Madrid, 1784-1790), Pedro Francisco Jiménez de Góngora y Luján, $1^{\text {st }}$ Duke of Almodóvar and State council since 1784 included, as a personal addition, a description of the Constitution of England based on the homonymous and previous work by De Lolme, in his incomplete adaptation in Castilian, under the pseudonym Eduardo Malo de Luque, of the famous and pre-revolutionary work by the abbé Thomas Raynal, titled Histoire Philosophique et Politique des Établissemens et du Commerce des Européens dans les deux Indes (Paris, 1775). Or publication of the work by Antonio Capmany in 1786, a Descripción política de las Soberanías de Europa, in which he referred to the British sovereignty without mentioning its rights and freedoms (of resistance to the arbitrariness of power, of the freedom of press or to judicial guarantees like habeas corpus, or to the institution of the jury), but he did refer in depth to the English legal system and Parliament as home to legislative authority ${ }^{53}$.

There is no trace, therefore, of any political model of historical Constitution in the minutes of the Board of the New Code, which deals with matters regarding ecclesiastical law and jurisdiction; not even in terms close to the aristocratic version by a duke of Almodóvar. In his Constitución de Inglaterra of 1785, he was concerned about defending the maintenance of an unequal hierarchical social order, insisting on royal pre-eminence and manifesting all his reservations about the party struggles in the House of Commons. Perhaps because it also contained dangerous references to individual freedoms (to civil equality and liberties, to property and security, to proscription of arbitrary detentions and the unjust or illegitimate exercise of power by the King and his agents) understood as absolute rights. Individual rights that were absolute because they were above the laws, superior to positive Law, as absolutely as the monarch was superior to the law in force. Hence, in the

53 Clavero, B., "Cortes tradicionales e invención de la historia de España», en VV. AA., Las Cortes de Castilla y León, 1188-1988, 2 vols., Valladolid, Cortes de Castilla y León, 1990, vol. I, pp. 147-195; De Lolme, Jean Louis, Constitución de Inglaterra, edición y estudio de B. Clavero, Madrid, CEPyC, 1992; Tomás y Valiente, F., "Génesis de la Constitución de 1812. I. De muchas Leyes Fundamentales a una sola Constitución», en AHDE, Madrid, 65 (1995), pp. 13-125; Id., "Las Cortes de España en 1809, según un folleto bilingüe cuya autoría hay que atribuir a un triángulo compuesto por un lord inglés, un ilustrado español y un joven médico llamado John Allen», en Initium, Barcelona, 1 (1996), pp. 753-815; e Id., "El Arzobispo de Santiago y las Cortes de 1810", en su Constitución: escritos de introducción histórica, Madrid, Marcial Pons, 1996, pp. 47-98; Moreno Alonso, Manuel, La forja del liberalismo en España. Los amigos españoles de Lord Holland, 1793-1840, Madrid, Congreso de los Diputados, 1997; Clavero, B., Happy Constitution. Cultura y lengua constitucionales, Madrid, Trotta, 1997; Varela Suanzes, Joaquín, «El debate sobre el sistema británico de gobierno en España durante el primer tercio del siglo xix», en José María Iñurritegui y J. M. Portillo (eds.), Constitución en España: orígenes y destinos, Madrid, CEPyC, 1998, pp. 79-108; Vallejo Fernández de la Reguera, Jesús, "Geo- grafía constitucional ilustrada», en HID, Sevilla, 25 (1998), pp. 685-715; e Id., Estudio preliminar a Duque de Almodóvar, Constitución de Inglaterra, Madrid, CEPyC, 2000, pp. XI-CXXVIII; Portillo Valdés, José María, Revolución de Nación. Orígenes de la cultura constitucional en España, 1780-1812, Madrid, CEPyC, 2000; y Conde Naranjo, Esteban, El Argos de la Monarquía. La policía del libro en la España ilustrada (1750-1834), Madrid, CEPyC, 2006, pp. 369-457. También Vallejo García-Hevia, J. M., La Monarquía y un ministro, Campomanes, Madrid, CEPyC, 1997, pp. 171-266; e Id., "Campomanes, gobernador del Consejo Real de Castilla y con- sejero de Estado (1783-1802)", en Dolores Mateos Dorado (ed.), Campomanes, doscientos años después, Oviedo, Universidad, 2003, pp. 211-256. 
Board of Laws of the Indies, the defence of the 'regalías' of the Crown continued to be the only concern of its members, at a time when the foundations of the absolutist European Monarchies had for some time been undermined, and their very structure was visibly teetering. This was so, despite their being experienced magistrates and ministers of the Royal Council of the Indies, such as: the dean, Manuel Lanz de Casafonda; or the prosecutor and future minister of Grace and Justice, Antonio Porlier, I Marquis de Bajamar in 1791; or the councillors Jacobo Andrés de la Huerta, Juan Manuel González de Bustillo, or Francisco Leandro de Viana, I Conde de Tepa since 1775. A 'regalismo' of these members-councillors, which, in many cases, remained anchored in the old theses of the Indian 'Real Patronato', typical of the 16th century; or, in the best of the cases, in those of the Royal Vicariate of the $17^{\text {th }}$ century, although its Bourbon interpretation, characteristic of $18^{\text {th }}$ century Spain, would not be lacking either, with the sovereign 'regalías patronales' being further extended in favour of the Crown and in pursuit of full Indian canonical jurisdiction. In this way, the members of the Board of the New Code became affiliated with the 'regalista' policy promoted by Campomanes from the Prosecutors Office of the Royal Council of Castile and, therefore indirectly agreed that as the 'regalías' of the Crown were understood as the exclusive rights of the Kings and of the Kingdoms of the Nation, and finally of Spain, the concept of a historical Spanish Constitution should become progressively consolidated. So, the deliberations made from 1781 to 1785 at the heart of this Indian compiling Board and their connection to a transcendental constitutional debate that had already been occurring with particular swiftness throughout an enlightened Europe can only be seen as unsatisfactorily implicit, exiguous and insufficient, and so disappointing.

Bourbon 'regalismo' of the $18^{\text {th }}$ century conti- nued with the 'regalista' practices of the Austrian dynasty in the $16^{\text {th }}$ and $17^{\text {th }}$ centuries, although with greater doctrinal exiguity. Consequently, Macanaz or Campomanes mostly made use of the materials drawn up by the jurists of the $17^{\text {th }}$ century, who, in their case, had considered what had been written since the period of the Catholic Kings. The 1680 Indian Compilation itself included the principles and praxis of this Austrian 'regalismo', and although the explicitness and intensification of some aspects of the spiritual government of the Indies, with clear royal interventions, meant a significant change in the ecclesiastical government of the Bourbons it was not substantial -especially under the rule of Carlos III and Carlos IV-, compared to the preceding dynasty. From the Council of the Indies and the Board of the New Code, ministers-councillors like the Conde de Tepa, Casafonda or Porlier particularly showed an attitude of reform in numerous matters concerning the Church. The 'regalías' of the Crown went from being considered by legal doctrine as special privileges granted to the Austrians by a pontifical concession, to become undisputable (inviolable, imprescriptible, untransmissible, indivisible) rights, inherent to royal sovereignty under the Bourbons. However, the Spanish Crown did not sustain an official doctrine regarding 'regalismo', or laws that presented the 'regalías' as royal rights inherent to royal sovereignty. To the contrary, all the royal provisions insisted on deriving the 'regalías' from the papal Bulls and briefs (concessions, privileges and prerogatives received from the Holy Seat), or, at most from immemorial custom. In turn the Apostolic See, far from accepting that the Kings of Spain were the Popes of the Indies, ruled the Church of the New World indirectly through the Monarchs themselves. In fact, the Apostolic See and the Roman Curia could not repudiate some Kings who permitted and never denied them the enjoyment of some 
extraordinary economic benefits that reached the coffers of the Spanish church, which the rest of the European Christian kingdoms did not consent to. Almost half the financial income that the Papacy received from the Christian Orb came from the Kingdoms of the Spanish Crown: a minimum of 500,000 silver ducats yearly on average in the $17^{\text {th }}$ century; and more than a million escudos a year in the $18^{\text {th }}$ century, coming from ecclesiastical benefits, papal exemptions, profits from 'espolios' and vacancies and other apostolic gifts and privileges. In this way, the Kingdoms of the Spanish Catholic Monarchy became the Indies of Rome, which found its Potosi in the profits of the Churches, and its Mita in the apostolic reserves. Neither did the Bourbons' official acceptance of the theses of the Royal Indian Vicariate constitute more than a formal variation of the Austrians' sustained and prevailing 'regalismo'. Theses that were formulated by the Religious Orders to be able to maintain their ecclesiastical privileges in America, put at risk after the Council of Trento (1545-1563), when the temporal sovereigns gave themselves the title of delegates and vicars of the Pope for the spiritual government of the New World. The assertion that all the authority of ecclesiastical government corresponded to the Crown, excluding the authority deriving from the holy Order, did not imply that it did not accept canonical Law, ecclesiastical legislation, and obviously Christian dogma and morality ${ }^{54}$.

Ismael Sánchez Bella, rightly concluded that far from being characterised by a marked 'regalismo', Book I of the New Code of the Indies of 1792 was simply a Compilation of the Indies of 1680, updated a century later, so that the 'regalis- ta' manifestations of the Austrians in the $16^{\text {th }}$ and $17^{\text {th }}$ centuries, and those of the Bourbons, and finally, the 'regalista' amendments and additions by Board of the new code would be reflected in this Book I. To be exact, the 'regalismo' of the Board -led by the criteria sustained primarily by Tepa, Casafonda and Porlier-, was undoubtedly that of least importance and relevance, since in the decade of 1780 when the board held its sessions, almost everything had already been done regarding 'regalista' issues. Very few new 'regalista' precepts of any importance were incorporated by the Board in their Book I of the New Code, with: clauses safeguarding the 'regalías' in the oath of allegiance to the Holy Seat, reserve in the appointment of ecclesiastical Notaries, a greater reduction in the jurisdiction of the Tribunals of the Church and the Inquisition, abolishment of personal immunity of the clergy in atrocious crimes and seditions, and the requirement of the civil authority's consent for the Cabildos in 'Sede Vacante' to appoint Judicial Vicars and General Vicars, and 'Visitadores'55.

In his study about legal-political royal power in the Modern Age, Salustiano de Dios was very attentive to concepts that were evolving politically during Modernity, like the natural reality of the kingdom, of territorial scope and remarkable practical consequences for the government of the Indies, for example, in an Empire as extensive as the Castilian empire, or for trade itself. This was without yet abandoning other more feudal concepts, like vasal, which ended up being combined with that of subject in a new dimension of political language. The category of citizen was even more important, as it was defended so much by the 're-

\footnotetext{
54 Sánchez Bella, I., Iglesia y Estado en la América Española, pp. 38-41, $45-52$ y 103-106; y García Añoveros, J. M. ${ }^{a}$, La Monarquía y la Iglesia en América, pp. 126-145.

55 Sánchez Bella, I., Iglesia y Estado en la América Española, pp. 263-265.
} 
galista' jurists in their works, especially regarding its newness, unlike the ideas of sovereignty or National Interest, not at all irrelevant but imported. It should be considered that by qualifying the ecclesiasts as citizens, and therefore subjects of the monarch, it was possible to subject them to the positive civil or political laws in the same way as laymen in the cases and disputes about 'recursos de fuerza', 'regio patronato' or financial contributions, all relevant to the common and public good. which the King was said to be the defender and protector of. Consequently, it was possible to avoid going against religion, pacifically balancing politics, law and Roman Catholic religion. De Dios verified, therefore, through the Castilian jurists of the Ancien Régime, both monarchist and catholic (Cevallos, Salgado de Somoza, González de Salcedo, Ramos del Manzano), that citizenship originated in connection with the extension of political law. A concept, which like 'Rule according to a Higher Law', would become a revolutionary term. It should be remembered that with the frequent conflicts that arose between the Spanish Monarchy and the Catholic Church, especially in matters of ecclesiastical powers, if the King's law was characterized as political, that is to say, for the common good, as political law it would be required -finally- of all citizens and members of the republic, whether laymen or ecclesiasts. It is clear that until the 1812 Constitution, there were no insurmountable difficulties for the elements of this triad of the Ancien Régime to remain united: Law, Religion and Politics. To sum up, the 'regalismo' of the legal experts at end of the $16^{\text {th }}$ and of the $17^{\text {th }}$ centuries, between Jerónimo de Cevallos and Pedro Frasso (so, Jerónimo Castillo de Bobadilla,
Gregorio López Madera, Francisco Salgado de Somoza, Juan del Castillo Sotomayor, Juan Bautista Larrea, Juan Solórzano Pereira, Pedro González de Salcedo, Francisco Ramos del Manzano) political law was extended to the ecclesiasts, the origin of citizenship was already in the Ancien Régime. The Roman Catholic religion did not prevent Politics from entering the Law ${ }^{56}$.

Before the rule of the Catholic Kings firm steps had been taken towards enhancing the preeminence of the monarch in his kingdom However, during the secular confrontation between the two powers, lay and religious, which required control over the ecclesiasts, it was precisely during Isabel of Castile and Fernando of Aragon's reign when certain manifestations of 'regalismo' began to take shape, like those of the 'patronato real', withholding papal Bulls and briefs, and civil hearings of the 'recursos de fuerza'. According to the abovementioned legal experts, the fact that no superior power was recognized in his kingdom meant, for the prince, subordination of lay subjects, including those endowed with jurisdictional privileges, as well as the subordination of ecclesiasts, in spite of their numerous freedoms and immunities. As already observed, the final integration of the ecclesiasts in the civil body of the Monarchy was brought about by the entry of politics and government, the ideas of sovereignty and National Interest and the condition or state of citizenship in Castilian jurisprudential doctrine since the end of the $16^{\text {th }}$ century. An objective for which the idea of political or civil law extended, because of its purpose of common or public good, to both clergy and laymen would also be useful, since both were citizens alike, parties or members of the Republic.

56 De Dios, S., "La doctrina sobre el poder del Príncipe en Jerónimo de Cevallos», "El papel de los juristas castellanos en la conformación del poder político (1480-1680)», "La Política en el Derecho. El tratado De lege politica de Pedro González de Salcedo", "Derecho, Religión y Política. La representación de Francisco Ramos del Manzano al Papa Urbano VII sobre la provisión de Obispados vacantes en la Corona de Portugal» y "La doctrina regalista en el doctor Juan del Cas- tillo Sotomayor», en su colectánea titulada El poder del Monarca en la obra de los Juristas castellanos (1480-1680), Cuenca, Universidad de Castilla-La Mancha, 2014, pp. 567-603, 665-681, 683-710, 711-758 y 759-793. 
For this reason, from Castillo de Bobadilla, but especially after Cevallos, even with the opposition of the theologists and the Holy Seat, an attempt was made to demonstrate that the 'recursos de fuerza' were not judicial or jurisdictional, but extrajudicial or political, and in this way overcome the obstacle of spiritual or supernatural jurisdiction belonging to the religious plane. This explains why the Holy Office ended up including many of the 'regalista' works by these authors in the Indices of prohibited books, since they were a threat against ecclesiastical immunities and freedoms.

On the other hand, there is a clear projection of the Barroque 'regalista' theses in the Enlightenment, intensifying absolutism and 'regalismo' in the $18^{\text {th }}$ century. An inherited 'regalismo', from the Austrians to the Bourbons, which De Dios detects with all its splendorous past in the Constitution of Cadiz, proclaimed as the Political Constitution of the Spanish Monarchy of 1812. Here is a simple, extremely significant enumeration for the sake of inventory: the overwhelming constitutional expression of the Roman Catholic denomination (art.12); the change in the title of political sovereignty that transcends from the King to the Spanish Nation but attributing the conservation and protection of religion to the new great political subject, the Nation, through wise and just laws on the same level as civil freedom, property, and the rest of the legitimate rights (arts. 4 and 12); the imprecise separation of powers grants and maintains - the monarch the power to have laws executed, the competence to present all ecclesiastical dignities and benefits of the 'patrona- to real' (art. 171.6.), as well as passing on or withdrawing pontifical Bulls and council decrees (art. 171.15.); while the courts, who had the power to apply laws in civil and criminal cases, are entrusted to hear the contentious matters related to the 'regio patronato' and the 'recursos de fuerza' (arts. 261.7. and 8., and 266) ${ }^{57}$.

The laws of the New Code, in the single Book I of 1792, were revised between at least four and five times. It should be asked what caused such slowness and delay in procedures, deliberations and agreements for adopting these newly compiled Indian laws. Was it the comings and goings of the ministers-councillors of their Boards, both the single Board and dual Board (Particular and Plenary), as well as the contradiction between the first examination and the second? The answer must be found in relation to the enigma of the cases of non-unitary validity -and there only being occasional and isolated validity of some of their laws- of the New Code of the Indies. They overcame insurmountable obstacles, both internally and externally: from the internal regime it was the zealous defence of their attributions, competences and functions by the traditional rather than bicentenary Council of the Indies in the face of the innovative and newly established Board of the New Code, which was an offshoot, since it was completely comprised of experienced Indian councillors ministers; and from the external regime, the fear of the reaction from the Holy Seat and the Church of America, given the overwhelming 'regalismo' of the New Code ${ }^{58}$. From a functional point of view, this slowness and delay and even

\footnotetext{
${ }^{57}$ De Dios, S., «A modo de epílogo» y «Epílogo del epílogo. Libertades eclesiásticas y poder civil, dos términos de difícil relación en la época tardía de los Austrias", en El poder del Monarca en la obra de los Juristas castellanos (1480-1680), pp. 795-851 y 853-874

${ }^{58}$ Son las tesis, respectivamente, de Muro Orejón, A., El Nuevo Código de las Leyes de Indias. Proyectos de recopilación legislativa posteriores a 1680, tesis doctoral, ya citada, prólogo de Rafael Altamira y Crevea, Madrid, 1929, pp. 33-34; y del presbítero Gómez Hoyos, Rafael, La Iglesia de América en las Leyes de Indias, Madrid, CSIC, Instituto Gonzalo Fernández de Oviedo, 1961,
} 
such contradictions that occurred throughout their long process of administration, which culminated in the same old impossibility of publishing the abundant compilation in 1792, must be inevitably blamed on and attributed to the ancient polisinodial regime of the absolute and universal Catholic Monarch of Spain with numerous Boards, Royal Councils and Secretariats. From an ideological perspective, this blame is enhanced because they were ministers-councillors of the Ancien Régime, or in the same sense members of the Board of the New Code, royal officials concerned and occupied with 'regalismo' and the absolute power of the sovereign, of the King. Hence, when it was truly codified, in the $19^{\text {th }}$ century, and under the regime of liberal rule according to a higher law, it was done from a General Codification Commission, no longer in a corporative synodal structure but in an administrative and state one ${ }^{59}$. From an institutional perspective, it should be agreed that the codification could not be carried out in truth under the aegis of the hierarchical and corporative organisation of the Ancien Régime; and from an ideological point of view, it is undeniable that for Casafonda, Domínguez, Huerta, Tepa, Bustillo, Porlier, Pizarro Piñeres, there were no citizens in the common sense of the word - not even for the 'regalistas' Casafonda, Tepa and Porlier, or for pro-ecclesiasts Bustillo, Huerta and Domínguez-, but only subjects of the absolute royal power; nor were there extemporaneous individual rights, there were only 'regalías' and other corporate prerogatives or privileges.

There is a clear precedent to the hypothesis that the non-publication of the whole of Book I can be contributed, in the end, to the rivalry and the spirit of emulation between the Royal and Supreme Council of the Indies and the Board of the New Code in the zealous defence of their respective legislative attributions, although both administrative entities were partially integrated by some of the same ministers-councillors. Víctor Tau Anzoátegui's hypothesis that the publication of Indian Politics by Juan Solórzano Pereira, in 1647 , halted the whole of the Indian compilation process is also very convincing. This author understands that the rivalry existing between the laws and the authors arises from the two principal ways of establishing law in the $17^{\text {th }}$ century. They were frequently combined, since the legal texts, given by the King, were accompanied by annotations or included in the texts. The authors explained or interpreted the law -deviating notoriously from the legal text on occasions-, with the support of the traditional civil and canonical jurisprudence of the common and Hispanic Rights which had auctoritas. But the rivalry between both ways of legal creation is also evident in the strong criticism the authors of the doctrine received from lawyers and laymen, founded especially on the uncertainty and confusion created by the array of opinions. The laws, however, gave accu-

pp. 56-57. Aparte de Trueba Gómez, Eduardo, Normativa de la Inquisición en Indias en el siglo xviii. Según el «Nuevo Código de Indias" de 1792, pp. 179-180, del ejemplar mecanografiado, sin lugar y sin data (¿1975?), de tesis doctoral inédita, depositada en la Biblioteca de la Facultad de Derecho de la Universidad de Sevilla, bajo la signatura B-4110.

\footnotetext{
59 Baró Pazos, Juan, La Codificación del Derecho Civil en España (1808-1889), Santander, Universidad de Cantabria, 1993, pp. 89 y ss.; Cobo del Rosal Pérez, Gabriela, y Navalpotro Sánchez-Peinado, Jesús María, «El proceso de formación de los Códigos entre dos poderes expansivos, legislativo y ejecutivo: Codificación penal y principio de legalidad en los inicios del Constitucionalismo español (1812-1843)», en E-Legal History Review, Madrid, 14 (2012), de http://www.iustel.com; e Iñesta Pastor, Emilia, "La Comisión General de Codificación (1843-1997): De la codificación moderna a la descodificación contemporánea», en AHDE, Madrid, 83 (2013), pp. 65-103
} 
rate and quick responses to these new situations, which was certainly very important for the New World. As the Kings' absolute power became more established, the condemnation towards any annotation or comment increased, since interpretation was considered to distort the precept.

In this sense, in the Dedicatoria al Rey, which heads the Sumarios de la Recopilación of 1628, Rodrigo de Aguiar y Acuña, minister-councillor, informed that the president of the Council of the Indies, Fernando, Fernando Carrillo, not only wanted the Compilation to be completed but that it should also be annotated or at least in accordance with royal laws and common law. Tau Anzoátegui infers from this that two compiling criteria existed at the beginning of the $17^{\text {th }}$ century: one, an exclusive legal compilation embodied in Rodrigo Aguiar and Antonio de León Pinelo; the other the compilation with doctrinal annotations, undertaken by Solórzano during his time as judge at the Court of Lima before 1618, and promoted by the president, Carrillo. For Tau, this would explain why in the period that both fundamental works by Solórzano (his De Indiarum lure, the first volume printed in 1629, and the second in 1639; and Política Indiana in 1647) were published, the Council of the Indies showed no interest at all in printing the Compilation completed in 1636, or in continuing with the edition of the Sumarios by Aguiar. However, there was a readiness and even pecuniary resources to support the publication of the works by Solórzano. It is plausible to consider that within the Council of the Indies, the doctrinal criteria of the jurists tended to prevail over legal criteria. Although there were those who, praised the laws as true jurisprudence, they considered that the Compilation must not include annotations of comments. The truth is that the legalist criteria of León Pinelo, which dominated the compiling Project of 1936, came to a standstill until Solórzano's death -and that of his doctrinal cri- teria- in 1655, although he had already retired in 1645. As from 1654, by request of León Pinelo, the Council of the Indies once again showed a renewed interest in the possibility of printing the Compilation. The change in their traditional position became apparent in their consultation of $11^{\text {th }}$ August 1660. Tau concludes, with brief references to how the disputes or discrepancies within the Council of the Indies could influence, or even halt a major compilation process:

“La corriente que enaltece la elaboración jurisprudencial se configura en torno a Solórzano, a través de sus obras De Indiarum luris (1629 y 1639) y Política Indiana (1647). Con ellas se atendía razonablemente al problema del Nuevo Mundo, pues se encontraban allí tratados -como había dicho en 1619-, " todos los puntos y materias particulares del derecho y gobierno de estas Indias". Aunque esta corriente englobaba también la posibilidad de imprimir una recopilación de leyes glosada -tal era la idea inicial del propio Solórzano-, es evidente que con el transcurso del tiempo parece quedar satisfecha en aquella producción jurisprudencial. Puede conjeturarse que este pensamiento aparece como dominante en el seno del Consejo, tal vez bajo el influjo solorciano, hasta casi la muerte del jurista. Es la época durante la cual -según lo he puntualizado-, los consejeros no demuestran mayor interés por la impresión de la Recopilación preparada por León, y hasta adoptan, en algún momento, una actitud próxima a la oposición cuando se ofreció una posibilidad cierta de llevarla a cabo. No aparece, por entonces, ninguna declaración del Consejo que relacionara el desgobierno de las Indias con la falta de una recopilación legislativa.

Así como Solórzano empezó trabajando paralelamente en los proyectos legislativo y juris- 
prudencial, también Antonio de León, con una buena formación humanista, se nos presenta en ambas sendas, pero, resignando sus intenciones iniciales de escribir una obra de conjunto sobre las Indias ( Tal era su proyectada "Politica de las Grandezas y Gobierno del Supremo y Real Consejo de las Indias", cuyo esbozo se plasmó en un opúsculo impreso en 1624 o 1625), concretaría, paulatinamente, sus energías en la labor legislativa, haciendo de la misma el centro de su actividad durante muchos años, y también el meollo de su concepción jurídica. Su proyecto de Recopilación, revisado por Solórzano, acabado y puesto en condiciones de ser impreso, no encontró, sin embargo, vientos favorables en el Consejo para este último paso. La impresión de la Recopilación no parecía un asunto urgente. Esta postura tardó en modificarse y, sólo en 1660, encontramos una decisiva declaración, a través de la cual, la Recopilación aparecía como de primera necesidad para atender un supuesto estado de caos o confusión que afectaba al gobierno de las Indias. Para entonces, también había muer- to León Pinelo.

Pese a este expresivo cambio de postura, no debemos olvidar que estamos incursionando en una historia de matices, en la cual se avanza lentamente, sin que nada nuevo aparezca de súbito, sin que nada antiguo se desvanezca espectacularmente. No se puede decir que una corriente sustituye a otra. Así como durante el período del posible influjo solorciano la presencia legalista tenía su lugar -desde luego que también en el propio pensamiento del jurista madrileño, así también durante la época posterior no podría decirse que el enfoque jurisprudencial fuese desplazado. Mientras la Recopilación fue ganando autoridad en el orden jurídico indiano, no por eso dejó de acudirse, e invocarse como derecho, a las obras jurisprudenciales"60

It is also necessary to examine the hypothetical causes behind the approval, sanction and enactment, but not its publication, of the ecclesiastical and 'regalista' Book I of the New Code in virtue of the well-known RD of Carlos IV, dispat-

\footnotetext{
60 Tau Anzoátegui, V., "Entre leyes, glosas y comentos. El episodio de la Recopilación de Indias», en el Homenaje al Profesor Alfonso García-Gallo, 5 vols., Madrid, Universidad Complutense, 1996, vol. III-1, pp. 267-283; la expresa cita literal, en las pp. 282-283; ahora en su colectá-nea ya mencionada, El Jurista en el Nuevo Mundo. Pensamiento, doctrina, mentalidad, BerlínFráncfort del Meno, Max-Planck Institut für europäischen Rechtsgeschichte, 2016, pp. 147-166. Hay reproducción facsimilar de la Política de Grandezas y Gobierno del Supremo y Real Consejo de las Indias, de Antonio de León Pinelo, en la Revista de Historia del Derecho $(R H D)$, Buenos Aires, 11 (1983), pp. 509-560, con una Advertencia del mismo V. Tau Anzoátegui. De este mismo autor, "La doctrina de los autores como fuente del Derecho castellano-indiano", en RHD, 17 (1989), pp. 351-408; y en El Jurista en el Nuevo Mundo. Pensamiento, doctrina, mentalidad, pp. 97-146. En general, sobre la materia, Altamira y Crevea, Rafael, "La intervención de don Juan de Solórzano en la Recopilación de Indias», en la Revista de Ciencias Jurídicas y Sociales, Madrid, 3 (1920), pp. 50-59; e Id., "La extraña historia de la Recopilación de Antonio de León Pinelo", en el Boletim da Faculdade de Direito da Universidade de Coimbra, Coimbra, 25 (1949), pp. 98-118, 280-304; 26 (1950), pp. 1-32 y 27 (1951), pp. 1-38; García-Gallo, Alfonso, "La Nueva Recopilación de las Leyes de Indias de Solórzano Pereira», en AHDE, Madrid, 21 (1951), pp. 529-606, luego reproducido en sus Estudios de Historia del Derecho Indiano, Madrid, Instituto Nacional de Estudios Jurídicos, 1972, pp. 299-365; García-Gallo, Concepción, "La legislación indiana de 1636 a 1680 y la Recopilación de 1680», en AHDE, 49 (1979), pp. 99-119; Muro Orejón, A., "La Recopilación de Indias de 1680», en Justicia, Sociedad y Economía en la América Española (siglos xvi, xvii y xviii). Actas y Estudios del VI Congreso del Instituto Internacional de Historia del Derecho Indiano, Valladolid, Universidad, 1983, pp. 53 y ss.; y Sánchez Bella, I., "Hallazgo de la Recopilación de las Indias de León Pinelo», en el Jährbuch für Geschichte von Staat, Wirtschaft und Gesellschaft Lateinamerikas, Colonia, 24 (1987), pp. 135-177, luego incluido en su colectánea de Derecho Indiano: Estudios, 2 tomos, Pamplona, Eunsa, 1991, t. II, pp. 1-62. Amén del estado de la cuestión proporcionado por Andrés Santos, Francisco J., "Los proyectos de Recopilación del Derecho Indiano en época de Felipe IV», en el Anuario da Faculdade de Dereito da Universidade da Coruña, La Coruña, 11 (2007), pp. 45-69.
} 
ched at the Royal Seat of Aranjuez on 25 $5^{\text {th }}$ March 1792. It is not plausible to attribute the non-publication of the New Code, with its enhanced 'regalismo' regarding the ecclesiastical matters in its Book 1, to the fear that the Church and its High Pontiff through the Roman Curia would protest to the King or they would become upset, which would lead to undesirable results for the delicate balance of the Alliance between the Throne and the Altar. At the end of the $18^{\text {th }}$ century, the Roman Curia and the High Pontiff were no longer alarmed or fundamentally concerned by the theory of the Royal Vicariate or the controversial issues of spiritual government between and the Crown and Church, the Empire and the Priesthood, as in those of the Papal Bull In Coena Domini, the royal exequatur, privileged ecclesiastical jurisdiction, 'recursos de fuerza', granting tithes, vacancies and 'espolios', the right of asylum, the temporal intervention in government by Religious Orders or the limits of the whole Patronato Real. Of course, there continued to be tensions, disputes and diplomatic wrangling between the royal and pontifical authorities about the limits in these and other connected issues, but within the already defined and secularly consolidated rules of the game, which excluded almost any danger of rupture in the relations between the Holy See and the Catholic Monarchy of Spain. In March 1792, as already in November 1790, a consultation was made for the royal approval of the twenty-six titles of Book I, but what concerned the Crown, and especially the Court of Carlos IV, was the French Revolution, which was so anti-monarchical and so anti-clerical, or better said anti-ecclesiastical, unquestionably irreligious. The National Constituent Assembly of France had approved the Civil Constitution of the Clergy on $12^{\text {th }}$ July 1790 , while the Third Family Pact with Spain of 1761 was dissolved. After fleeing Paris Louis XVI was arrested in Varennes on $29^{\text {th }}$ June 1791 , and on $14^{\text {th }}$ Sep- tember of the same year he was made to swear on the revolutionary Constitution, which deposed him of his powers as absolute Monarch of the Ancien Régime. It was not long before the Monarchy in France was abolished on $25^{\text {th }}$ September 1792, after the occupation of the Tuileries on $10^{\text {th }}$ August by the people of Paris. Finally, the citizen Louis Capet was guillotined on $21^{\text {st }}$ January 1793 , and France became a Republic. It is not surprising that the abovementioned consultation of $2^{\text {nd }}$ November 1790 by the Board of the New Code was not resolved by the Catholic King of Spain until a year and a half later on $25^{\text {th }}$ March 1792. This delay was clearly due to political reasons, and not for reasons of the radical 'regalismo' in the contents of Book I.

Neither is it surprising that the first secretary of State and the Office of Carlos IV, José Moñino y Redondo, I Conde of Floridablanca, should see it as advisable to defer or prolong the resolution about the consultation of $2^{\text {nd }}$ November 1790 , with such uncomfortable and inopportune content. This was to be expected from the author of the cordon sanitaire policy, with indispensable support from the Holy Office of the Inquisition, ecclesiastical authorities in general, from prelates to parish clergies, even from the friars of the numerous religious Orders, especially since they were confiscating the revolutionary propaganda from the north of the Pyrenees (books, pamphlets, leaflets, poetry, novels, drawings, paintings, printed material in general), and pursuing supporters of revolutionary ideas in the peninsular territory. It was not at all politically wise in 1790 to try and impose on America an ecclesiastical regulation, which was of a more 'regalista' nature than the one in force since 1680. Particularly since Church authorities were collaborating so actively and effectively with the secular power and civil authorities: stopping the French revolutionary fervour that threatened Europe, with its ideas that were 
so dangerously subversive to the old absolutist Monarchies and paradigmatically to the most extensive, wealthiest, and most ancient of them all, the Hispanic Monarchy of the surviving branch of the Bourbon Dynasty. In short, it is understandable that Floridablanca, ally to the Church and the Inquisition in 1790, in his fight against the Revolution, the Republic and the Irreligion in France, should consider it little or not at all advisable to approve a regulation so decidedly 'regalista' as the contents in Book I of the New Code of the Indies. Besides, it was absolutely unnecessary in those unstable times given the peaceful and contrasted validity of the centenarian Compilation of the Indies and its Book I. Was it conceivable that Floridablanca should decide to publish a legislation which continued to undermine the broad privileges and prerogatives of his indispensable ally, the Spanish church and by extension the universal Church with its head the Roman Pontiff at the forefront? Especially, in such hazardous and disturbing times, with the disruption of everything historically known, which culminate in the War of the Convention (1793-1795), the instability imposed by Napoleon Bonaparte throughout absolutist Europe as far as the boundaries of Russia and Spain, the War of Independence (1808-1814), and that great Hispanic internal instability -the successive reigns of Fernando VII (1808, 1814-1820, 1823$1833)^{61}$.

The impact from the introduction of a clear change of direction in the foreign policy of the Spanish Monarchy was clearly due to Floridablanca's successor, Pedro Pablo Abarca de Bolea, X Conde de Aranda, predecessor to the current minister of State Manuel Godoy, who became interim secretary of the Office of State and dean of the Council of State on 28 ${ }^{\text {th }}$ February 1792. At that time, the competent minister of Grace and Justice of the Indies, Antonio Porlier, I Marqués de Bajamar dared to resolve the retained and postponed consultation of $2^{\text {nd }}$ November 1792, by enacting the New Code in its Book I on 25 ${ }^{\text {th }}$ March, but without any publicity, and simply a reserved, irregular, casuistic application. José Antonio Ecudero made an in-depth and thorough analysis of the so-called Memorial de Aranda of 1783. In this Memorial, the dignitary from Aragon would have tried to avoid the foreseeable loss of the Hispanic Indies in the hands of the new and emerging continental power of the United States of America, after the Versailles Peace of $3^{\text {rd }}$ September 1783, which led to the end of the War of Independence of the Thirteen Colonies of North America, and America's independence from its own metropolis the United Kingdom of Great Britain. Aranda also proposed the conservation of the islands of Cuba and Puerto Rico only, and the establishment of the three Spanish Bourbon princes as Kings of the New Spain in the city of Mexico, of Peru in Lima and of Tierra Firme in Santa Fe de Bogotá, with the King of Spain adopting the title of Emperor. However,

\footnotetext{
${ }^{61}$ Defourneaux, Marcelin, Inquisición y censura de libros en la España del siglo xviii, versión española de J. Ignacio Tellechea Idígoras, Madrid, Taurus, 1973 (1.a ed. en francés, París, Presses Universitaires de France, 1963), pp. 75-215; Jiménez Monteserín, Miguel, «Inquisición y Revolución Francesa (1788-1808). Vigilancia y cordón sanitario», en Joaquín Pérez Villanueva y Bartolomé Escandell Bonet (dirs.), Historia de la Inquisición en España y América, vol. I. El conocimiento científico y el proceso histórico de la Institución (1478-1834), Madrid, BAC, 1984, pp. 1305-1312; y Hernández Franco, Juan, La gestión política y el pensamiento reformista del Conde de Floridablanca, Murcia, Universidad, 1984, pp. 239-250 y 549-570. Asimismo Prieto García, Rosario, La Revolución Francesa vista por el embajador de España, Conde Fernán- Núñez, Madrid, Fundación Universitaria Española, 1997; Badorrey Martín, Beatriz, Los orígenes del Ministerio de Asuntos Exteriores (1714-1808), Madrid, Ministerio de Asuntos Exteriores, 1999, pp. 154-234; y Vallejo García-Hevia, J. M., "La última máscara del Rey. Las Cortes de Castilla de 1789 en la España del Antiguo Régimen», en María Dolores del Mar Sánchez González (coord.), Corte y Monarquía en España, Madrid, Centro de Estudios Ramón Areces y Universidad Nacional de Educación a Distancia, 2003, págs. 191-258.
} 
José Antonio Escudero has concluded that the author of this Memorial, the original of which has not been conserved, was not the Conde de Aran$\mathrm{da}$, but a falsification made more than 40 years later, towards 1824 or 1825 , among the exiled enemies of Godoy in Paris, from the circle of Andrés Murie and the Duke of San Fernando, in a political manoeuvre that would have led to the historical rehabilitation of Aranda, former hostile and mortal enemy of the favourite of the reign of Carlos IV. However, although Aranda was not the author of the Memorial of 1783, falsely and erroneously attributed to him, as minister of State or the dean of the Council of State regarding the future ungovernability of America, he was concerned in life, as were other contemporary politicians from the Embassy of the Catholic King before the Court of Christianity in Paris, about the harmful example of some independent United States and about the convenience of solving the problem with the Overseas Monarchies ${ }^{62}$. In this case, it would not have harmed Aranda's politics to reaffirm the sovereign 'regalías' in the Viceroyalties of America with the enactment of Book I of the New Code. But in spite of this, he decided to go along with the political guidelines of his bitter rival, the conde de Floridablanca, and avoid the publication of regulations in order not to arouse material or financial and spiritual suspicions, anger, confrontation or explicit resistance by the Church which would lead to difficulties in its collaboration with the civil authorities to eradicate the French revolutionary danger, also in the far-off New World.

\section{COLOPHON}

\footnotetext{
62 Escudero, J. A., El supuesto Memorial del Conde de Aranda sobre la Independencia de América, México, Instituto de Investigaciones Jurídicas, Universidad Nacional Autónoma, 2014, pp. 83-98, 137-210 y 215-226.
} 


\section{THE BOARD OF THE NEW CODE OF THE INDIES (1776-1820): OBSERVATIONS AND \\ CLARIFICATIONS FOR A REVISED INTERPRETATION \\ Dr. José María Vallejo Garcia-Hevia}

far, already in 1792, the New Code and with it the royal absolute power of the society that was subjected to, decided to remain autistic before the irruption, conceived throughout the most part of the $18^{\text {th }}$ century, of this new man, in his new state power. It is however true that all the deep-rooted innovations for conservation, development, reform or revolution were in open rupture with or mostly in prolonged disregard for the reviled Ancien Régime, that is why it is discredited as such a failure. On examining the wrecked remains of the New Code, it is possible to calibrate the scope of such a failure. In fact, Savigny would not take long in understanding, in his famous controversy with Anton F. J. Thibaut in 1814, that codifying was modifying the form of authority of the pre-existing law, that is to say of the historically compiled law:

“En otras palabras, [Friedrich Carl von] Savigny comprendió claramente que la Codificación, aun cuando contuviese sólo Derecho preexistente, modificaba, en él, la forma de la autoridad. Ésta establecía un nuevo orden formal, fijaba un nuevo horizonte y se imponía como un nuevo cosmos, en cuyo seno las cosas viejas se cargaban de significados nuevos. Lo que había sucedido en el ámbito de la Compilación justinianea se repetía ahora en materia de codificación: la novedad no estaba provocada por la sustitución material de insti- tuciones ya en desuso, sino precisamente por el distinto valor que les confería el hecho de encontrarse reordenadas y recogidas a tenor de nuevos principios sistemáticos. La quintaesencia del valioso descubrimiento savigniano es precisamente el haber comprendido que toda codificación renovaba la jerarquía de las fuentes $y$, al hacerlo, creaba nuevas interdependencias e innovaba, tanto en el ámbito formal como en el material"63

\footnotetext{
63 Caroni, Pio, "La Codificación en la obra de Savigny», en sus Escritos sobre la Codificación, traducción de Adela Mora Cañada y Manuel Martínez Neira, Madrid, Universidad Carlos III, 2012, pp. 1-43; la cita literal, en la p. 6. Siendo la monografía originaria: Caroni, P., "La cifra codificatoria nell'opera di Savigny", en los Quaderni Fiorentini per la Storia del Pensiero Giuri- dico Moderno, Florencia, 9 (1980), pp. 69-111. Una valiosa síntesis de la ideas codificadoras de Anton Friedrich Justus Thibaut, de las ideas anticodificadoras de Friedrich Carl von Savigny, y de la célebre polémica suscitada entre ambos, el llamado debate sobre la Codificación (Kodifikationsstreit), en Pau Pedrón, Antonio, Thibaut y las raíces clásicas de Indefenso I Romanticismo, Madrid, Trotta, 2012, cap. IX, pp. 61-69.
} 